Hispania Sacra, LX

121, enero-junio 2008, 95-130, ISSN: 0018-215-X

\title{
IGLESIA Y PODER EN EL MARQUESADO DE VILLENA. LOS ORÍGENES DE LA COLEGIATA DE BELMONTE
}

\author{
POR \\ Carlos Ayllón Gutiérrez \\ Instituto de Estudios Albacetenses Don Juan Manuel
}

\section{RESUMEN}

La profunda enemistad existente entre Juan Pacheco, marqués de Villena, y el obispo de Cuenca, Lope de Barrientos, fue un factor fundamental en la fundación de la iglesia colegial de Belmonte a finales de 1459. Las circunstancias de la fundación y la incorporación de rentas para financiar el nuevo cabildo reflejan las relaciones de la familia Pacheco con respecto a la Iglesia conquense. Estas relaciones serán con frecuencia hostiles, principalmente durante el obispado del cardenal Riario (1493-1518).

PAlabras ClaVE: Siglo XV, Marquesado de Villena, Familia Pacheco, Belmonte (Cuenca), Luchas de poder, Tráfico de beneficios, Colegiatas.

\section{ABSTRACT}

The deep existing hatred between Juan Pacheco, Marquess of Villena, and the bishop of Cuenca, Lope de Barrientos, was a key factor in the foundation of Belmonte's collegiate (school) church at the end of 1459. The circumstances of the foundation and the incorporation of revenues to finance the new chapter reflect the relationships of the Pacheco family with regard to the Church of Cuenca. These relationships will be often hostile, mainly during the bishopric of the cardinal Riario (1493-1518).

KEY WORDS: $15^{\text {th }}$ Century, Marquisate of Villena, Pacheco family, Belmonte (Cuenca), Power fight, Trade of benefices, Collegiate churches.

Recibido/Received 12 mayo 2007

Aceptado/Accepted 23 junio 2007 
A lo largo del siglo XV las principales casas nobiliarias establecerán unas relaciones especiales con la Iglesia principalmente en aquellos lugares en los que ejercen su señorío. A diferencia de épocas anteriores, este tipo de vínculos ya no van a consistir en la simple promoción de conventos o en el establecimiento de memorias funerarias. Por el contrario, los nobles emplean sus iniciativas eclesiásticas como un eficaz instrumento para la consecución de sus objetivos políticos. A este fin emprenden la construcción de iglesias, el apadrinamiento de beneficiados promovidos a parroquias o el desvío de rentas eclesiásticas en beneficio propio, así como el tejido de toda una red de influencias sociales en las que no escasean los emparentamientos con altos clérigos ni el establecimiento de clientelas clericales. A veces incluso se van a servir de sus empresas religiosas para adoptar una actitud de fuerza frente a altas instancias eclesiales.

Un caso muy ilustrativo de esta línea de actuación de la alta nobleza lo hallamos en la influencia que la familia Pacheco ejerce en su villa de Belmonte, en la que acomete importantes acciones referidas al ámbito de la Iglesia. En realidad los Pacheco intentan hacer de la villa una suerte de sede señorial, a la que quisieron convertir en un foco eclesiástico a modo de villa cuasiepiscopal; de ahí que sus obras repercutirán en la dinámica clerical de la población manchega y aun del obispado conquense ${ }^{1}$. Especial importancia tendrá la actividad de Juan Pacheco -marqués de Villena, y por ende señor de Belmonte, entre 1445 y 1467- y de su hijo y su cesor Diego López Pacheco (1467-1529)2.

La vinculación de esta villa a la familia Pacheco se remonta a 1398, cuando Enrique III otorga Belmonte con sus aldeas al portugués Juan Fernández Pacheco en forma de pleno señorío en recompensa por su colaboración con la corona castellana frente a Juan I de Portugal. El patriarca de los Pacheco llevará a cabo a partir de este momento algunas fundaciones religiosas que supondrán el inicio de una tendencia de su linaje caracterizada por una estrecha relación y una trayectoria paralela entre la casa señorial y la vida religiosa del núcleo. Así pues, durante el siglo XV los miembros de la familia harán construir un hospital bajo la advocación de San Andrés (ca. 1415), la ermita de Nuestra Señora de Gracia (1428), un convento de frailes observantes de San Francisco (1457), un monasterio de Terciarias Franciscanas (1483) y otro de monjas clarisas de la Inmaculada Concepción (1490); y también bajo el señorío de Diego López Pacheco se gestiona el traslado del convento de dominicas de La Alberca a Belmonte, en el

\footnotetext{
${ }^{1}$ En este sentido, las acciones de Juan Pacheco son bien diferentes a las que el siglo anterior llevó a cabo en La Mancha don Juan Manuel, su antecesor como señor de Villena.

2 Juan Pacheco cede a su hijo la titularidad del marquesado en 1467, cuando asume el maestrazgo de Santiago.

Hispania Sacra, LX

121, enero-junio 2008, 95-130, ISSN: 0018-215-X
} 
inmueble del propio palacio señorial ${ }^{3}$. Pero entre todas las empresas eclesiásticas que tuvieron lugar en la Mancha oriental, sin duda merece ser destacada la transformación de la iglesia parroquial de San Bartolomé de Belmonte en colegiata, a instancias de Juan Pacheco.

Esta parroquia siempre fue objeto de las atenciones de los señores de la vi1la. En primer lugar Juan Fernández Pacheco escoge dicho templo como panteón de su familia. En su capilla mayor se harán enterrar él y su esposa Inés Téllez de Meneses. La misma decisión tomarían años más tarde los segundos señores de Belmonte: doña María Pacheco, hija de los anteriores, y su esposo Alonso Téllez Girón, padres del futuro marqués de Villena, Juan Pacheco. También en la parroquial de Belmonte será enterrada Guiomar, hija de Rodrigo Rodríguez de Avilés -señor de Martín Ovieco- y nieta de Juan Fernández Pacheco. Habida cuenta de esta función funeraria, el patriarca y primer señor de la villa otorgará generosas donaciones que engrandecerán a la iglesia de Belmonte, unas iniciativas que ocasionarán que el templo adquiera especial notoriedad dentro de la diócesis conquense.

Probablemente el propio monarca Juan II también contribuyó al auge de la parroquia, pues con motivo del Concilio de Basilea, envió como representante de la iglesia castellana a don Álvaro de Isorna, obispo de Cuenca, con la circunstancia de que el 20 de mayo de 1436, al poco de iniciarse la asamblea, el papa Eugenio IV expidió una bula por la que concedía indulgencia de cuarenta días a quienes con su trabajo o con sus aportaciones económicas contribuyeran a la construcción del campanario y de la sacristía del templo. Dado que ambos elementos se encuentran situados a los pies del edificio, ha que entenderse que desde algunos años atrás se venía reconstruyendo la iglesia en la villa ${ }^{4}$.

La restauración del marquesado de Villena en la persona de Juan Pacheco es un hecho de primera magnitud dada la importancia de sus dimensiones territoriales, su población, sus rentas y su posición estratégica a caballo entre Castilla y Aragón. También será decisiva en la vida del clero comarcal, y de manera muy especial en la del que oficia en Belmonte. Para establecer en esta población su corte particular, Juan Pacheco destina numerosas rentas que financiarán distintas empresas referentes al clero, tanto el regular como el parroquial. Esta actividad contempla asimismo la ampliación cuantitativa y cualitativa de las instituciones eclesiásticas del núcleo poblacional, de manera que Belmonte se

\footnotetext{
${ }^{3}$ BNE, Mss 13124, ff. 166r-170r. L. AndúJar OrTEga, Belmonte, cuna de fray Luis de León. Su colegiata, Cuenca 1995, 318 pp.

${ }^{4}$ Archivo Parroquial de Belmonte (APB), Carpeta de bulas, no 2 (Basilea, 20-mayo-1436). La riquísima documentación del APB se halla aún sin catalogar y se distribuye sin numerar en cajas rotuladas con dudoso criterio. A esta rotulación aludiré a modo de signatura documental. Sólo un puñado de bulas y otros documentos se encuentran numerados y guardados en la citada carpeta diferenciada.
} 
acaba convirtiendo en una segunda sede religiosa dentro de la diócesis de Cuenca. Dos factores inciden de forma decisiva en el ánimo de don Juan para transformar la iglesia de la villa manchega: por un lado su intención inicial de hacerse enterrar en ella; por otro su pretensión de ennoblecer el lugar en que reposan los restos de sus antepasados. Todo ello aparece explícito en el primer testamento, que redacta el 27 de diciembre de 1469 (no en 1470 como nos hace creer Franco Silva pues en las fuentes se indica este año, pero, como sabemos, en el siglo XV se consigna el nuevo año a partir del día de Navidad) ${ }^{5}$. En el documento Juan Pacheco pide que su cuerpo sea inhumado en la capilla mayor de la iglesia colegial de San Bartolomé; sin embargo, cuando dos años más tarde dicte un segundo y definitivo testamento, ya habrá cambiado su decisión y ordena que sea sepultado en el monasterio segoviano de El Parral. Pero otro elemento pesará en el empeño de Juan Pacheco de crear un núcleo de gran peso eclesiástico dentro de sus tierras, y es la profunda enemistad que se profesaron mutuamente él y el obispo de Cuenca don Lope de Barrientos.

Juan Pacheco es uno de los hombres que muestra en su época una mayor clarividencia acerca de la fuerza política de la Iglesia. Cuenta con el apoyo de importantes clérigos en su dinámica de intrigas durante toda su carrera, e incluso algunos de ellos pertenecen a su propio linaje; si bien por otra parte, también tuvo altos cargos de la Iglesia enfrentados a su persona en asuntos políticos. Aparte del conocido antagonismo con Lope de Barrientos, también los Mendoza, con distintos miembros de su clan instalados en las altas esferas eclesiásticas, serán perpetuos oponentes del hábil marqués de Villena, lo que permite constatar la consideración que los asuntos de Iglesia tendrán dentro de la política pachequista, y ya no sólo en lo que respecta al clero catedralicio, sino también al que opera en los pueblos. De ahí su interés en hacer de Belmonte una villa bien dotada de clérigos y construcciones religiosas de todo tipo. Por ello crea la colegiata, instituye el citado convento franciscano y refunda el hospital de San Andrés, cubriendo con estas acciones tres parcelas distintas de tipo eclesial, relativas al clero secular, al regular y al asistencial, respectivamente, lo que en definitiva consolida la relación del marqués con los distintos estratos de la clerecía local y aun de la población seglar.

Ya en los años cuarenta, al poco tiempo de recibir el título de marqués con su señorío, don Juan Pacheco había intentado erigir un convento de franciscanos observantes en la diócesis conquense, aunque no será hasta mediados de la década siguiente cuando comience la edificación del monasterio de San Francisco de Belmonte, aprovechado el solar de una antigua ermita. Al inicio de las obras Pacheco solicitó a Calixto III le concediese licencia para llevar adelante

\footnotetext{
5 A. Franco Silva, «Los testamentos de Juan Pacheco», en Congreso de Historia del Señorío de Villena, Albacete 1986, p. 159.

Hispania Sacra, LX

121, enero-junio 2008, 95-130, ISSN: 0018-215-X
} 
la fundación, con la condición de que el obispo de Cuenca quedase al margen del proceso constitutivo. El marqués no quiere, pues, que Barrientos pueda impedir su gran empeño de hacer de Belmonte una especie de capital espiritual de su señorío. En consecuencia, el primer papa Borja otorga su autorización en tales términos en febrero de 1457 mediante su bula de fundación del convento ${ }^{6}$.

Los frailes que se instalan en Belmonte proceden de la comunidad observante de Santoyo, pero lo más significativo es que la orden franciscana sea la elegida y promocionada por Pacheco: no olvidemos que se trata de la principal congregación en rivalidad con la Orden de los Hermanos Predicadores a la que pertenece el obispo don Lope de Barrientos.

Otro de los proyectos pachequistas es el Hospital de San Andrés de Belmonte. Juan Fernández Pacheco había fundado dicho hospital hacia 1415, y más tarde Alonso Téllez Girón renueva sus vínculos y aumenta su dotación económica. Después tocará el turno a Juan Pacheco para proseguir el engrandecimiento de la fundación. En realidad lo que hace es fundar un nuevo hospital, al cual otorga su palacio en Belmonte y anexa el antiguo hospicio, si bien manteniendo la advocación que eligiera su abuelo materno. Como nueva dotación material del hospital, Juan Pacheco aporta cincuenta mil maravedíes de juro situados en las tercias de la villa de Belmonte, además de unas heredades suyas de pan llevar de La Osa, otra también de pan llevar con casas, viñas y tierras en Tresjuncos, y diez aranzadas de viña «en dos suertes en Velmonte a Cannada Hermosa» (tal vez emplazadas en Villarejo de Fuentes). Tanto la concesión del palacio, como la anexión del viejo hospital al nuevo, y la entrega de las fincas se verificaron en sendas escrituras que Pacheco expidió en Villarrobledo el 10 de junio de 1457 (aunque quizá sólo confirmó la dotación inicial) ${ }^{7}$.

Para reafirmar su autoridad, Pacheco consiguió en 1458 una bula de Calixto III por la que éste de nuevo mandaba expresamente que el obispo de Cuenca no se entrometiera en visitar el hospital. Asimismo logró obtener el derecho de patronato en virtud de varias letras apostólicas de Pío II libradas al año siguiente $\mathrm{y}$, al igual que hicieran sus referidos antepasados redactó nuevas ordenanzas para el régimen de la casa, aprobando la validez de los estatutos anteriores ${ }^{8}$.

Antes de culminar su obra de transformación de Belmonte, Juan Pacheco entabla estrechos lazos con las más altas instancias eclesiásticas a fin de ganar-

\footnotetext{
${ }^{6}$ Ibidem, p. 313.

${ }^{7}$ En el citado manuscrito de la Biblioteca Nacional se alude a que Juan Fernández Pacheco había cedido al hospital «varias heredades en Velmonte, La Ossa y Tres Juncos» (BNE, Mss 13124, f. 169r), quizá por confusión con la donación de su nieto, o bien porque Juan Pacheco aumenta o confirma la dotación primigenia.

${ }^{8}$ BNE, Mss 13124, f. 170r. Entre las escrituras de gobierno del hospital se debió de recoger la facultad concedida en 1455 por Calixto III a los pobres del hospicio para que pudiesen escoger confesor.
} 
se un respaldo cualitativo en sus referidas intrigas políticas y para gozar, además, de determinadas prerrogativas que sólo podría obtener de la Sede Apostólica. El acercamiento al setabense Calixto III cristaliza en 1455, a los pocos días de su elección como papa, en la concesión por parte de este pontífice a Pacheco de seis beneficios simples o préstamos vacantes o por vacar -en cuyo caso se le garantizaría su reserva- en premio a su fidelidad a la Santa Sede ${ }^{9}$. Además en esta época y merced a sus tratos con Roma, Juan Pacheco obtiene para sí y para su segunda esposa, María Portocarrero, distintos privilegios eclesiásticos, como el que les dispensa de comer lácteos y otros productos sujetos a abstinencia durante la Cuaresma (1455). Poco después los esposos reciben la validación de su matrimonio (1457), la legitimidad de la descendencia habida por ellos antes de los esponsales y otras prerrogativas referentes a la confesión $(1471)^{10}$.

Por último, entre las acciones religiosas emprendidas por Juan Pacheco hay que citar también su firme determinación para colaborar con las pretensiones del papa Eugenio IV (muerto en 1447) para reformar la comunidad agustina establecida en el vecino Castillo de Garcimuñoz para conducirla a la observancia. Pacheco, llevado por una visión objetiva de la realidad, informará al pontífice Pío II de las dificultades para llevar a cabo la reforma, a tenor de la dificultad para hallar agustinos reformados en la región, por lo que ruega al papa que busque alguna solución contundente. Así, años más tarde, en enero de 1459, el nuevo pontífice, Pío II, sugiere un efectivo remedio que consiste en lanzar un ultimátum a los frailes para que abracen la reforma o de lo contrario tendrían que ser expulsados de su casa y sustituidos por hermanos franciscanos. La propuesta papal obtuvo un claro éxito: los agustinos abrazaron la reforma de inmediato ${ }^{11}$.

\section{La COLEGiata de SAN Bartolomé. PReCEDENTES y PROCESO DE FUNDACión}

A mediados del siglo XV, la iglesia parroquial de San Bartolomé de Belmonte es un templo cuya relevancia destaca con claridad por encima de las demás iglesias de toda la comarca, gracias a la amplia feligresía -que aporta un sustancioso diezmo- y a los impulsos tanto de la nobleza local como de otros vecinos de Belmonte. Su transformación en templo colegial constituye, como he señalado, el principal proyecto pachequista relativo a la Iglesia llevado a cabo dentro de la tierra de su marquesado. Es significativo que todos

\footnotetext{
${ }^{9}$ AHN Nobleza, Frías, Carpeta 8, n ${ }^{\circ}$ (El documento está fechado erróneamente en 11 de las calendas de abril (22 de marzo) de 1455, en Roma, pues el papa fue elegido el día 8 de abril de ese año).

${ }^{10}$ AHN Nobleza, Frías, 112, nº 3 (Roma, 17-abril-1455), 4 (7-marzo-1457) y 5 (Segovia, 2-junio1457); ASV, Brevia, Paulo III, 1470-1471, f. 97r.

${ }^{11}$ J. DíAz IbáÑ̃z, Iglesia, sociedad y poder en Castilla. El obispado de Cuenca en la Edad Media (siglos XII-XV), Cuenca 2003, p. 309.

Hispania Sacra, LX

121, enero-junio 2008, 95-130, ISSN: 0018-215-X
} 
aquellos que ostentaron el señorío en Belmonte contribuirán a su manera al engrandecimiento del templo parroquial de la villa y de sus clérigos servidores, lo que convierte a la colegial en toda una empresa colectiva del linaje Pacheco.

Poco después de que el poderoso valido acceda al marquesado de Villena pondrá especial perseverancia en hacer de esta parroquia un edificio de la mayor dignidad y relevancia posibles. En 1456, antes de iniciar el proceso de institución canónica y coincidiendo con la rehabilitación del castillo como fortaleza y palacio particular, el marqués costeó la reconstrucción y reforma del templo haciendo reedificar la capilla mayor, toda vez que hasta entonces la iglesia de San Bartolomé era una construcción de modesta factura. Este hecho habrá de constituir el punto de partida para la creación de la colegiata.

Entre las causas que llevan a Juan Pacheco a llevar adelante esta iniciativa hay razones de índole espiritual, pero también personal y político difíciles de separar. Como tantos proyectos religiosos, la creación de la colegiata tiene un significado votivo que se orienta a la salvación de las almas del fundador y de los allegados suyos que él determine. Además toda ampliación de un templo se concibe como una aportación al servicio espiritual de la comunidad.

Pero la iglesia colegial forma parte en realidad de ese programa pachequista encaminado a hacer de Belmonte una sede señorial a la que deberá corresponder un esplendor y una magnitud de especial suntuosidad y brillo. Todo el engrandecimiento al que somete a la villa, en especial en lo relativo a las construcciones religiosas está encuadrado en un proceso un tanto exhibicionista de representación del poder señorial ante los súbditos y ante los demás elementos sociales. En este sentido el señor es consciente de que el propio pueblo acoge de manera positiva la mejora de su templo parroquial, un elemento que por otra parte contribuye a proporcionar cohesión vecinal a la villa.

Asimismo como parte de esa muestra de poder y del orgullo de linaje, se halla el interés por conservar y mejorar el citado panteón familiar creado por Fernández Pacheco, precisamente en esta época en que la Iglesia acentúa la relación ilusoria de los vivos con los muertos, a tenor del desarrollo que imprime a las capellanías y a los ceremoniales de exequias y aniversarios. Y tampoco olvidemos que en esta iglesia el propio Juan Pacheco fue bautizado, lo que subraya el valor sentimental que tenía para él.

Sin embargo, el factor más determinante en la política religiosa de Juan Pacheco en sus dominios manchegos y principal acicate que lo mueve a crear esta colegiata radica en su abierta enemistad con Lope de Barrientos, nombrado obispo de Cuenca en 1445, justo cuando Pacheco va a recibir el título de marqués de Villena. Este enfrentamiento, en realidad concerniente a la esfera política, tendrá su repercusión en el gobierno de la clerecía del señorío de Villena en 
el partido de Cuenca, lo que revela una vez más la falta de separación entre los ámbitos político y eclesiástico.

Nacido en Medina del Campo hacia 1382, don Lope pertenece a uno de los principales linajes de su tierra natal. En 1429 inicia su carrera política cuando Juan II lo nombra preceptor del príncipe Enrique, una tarea que le granjeó un notable ascendiente en la Corte y en particular ante la familia real, de tal modo que en 1434 pasa a constituirse en confesor del propio rey. Con el apoyo de éste accede en 1438 al obispado de Segovia; pero dos años más tarde se ve obligado a abandonar la sede para pasar a la de Ávila. Este traslado, que provocó un gran pesar en el rey, al parecer se debió a que ya entonces había aflorado la enemistad entre Lope de Barrientos y Juan Pacheco, favorito del príncipe Enrique que pasaba largas temporadas en Segovia ${ }^{12}$.

Las diferencias entre los dos políticos hay que buscarlas en que Barrientos se erige en uno de los más firmes defensores de la autoridad regia frente a las pretensiones nobiliarias, aunque su estancia simultánea en la casa del rey pudo ocasionar alguna fricción mucho más personal. Aunque en algunos momentos posteriores, Barrientos y Pacheco unieron sus fuerzas -si bien más por intereses particulares que por verdadera amistad-, la rivalidad entre ambos continúa a lo largo de los años siguientes. A principios de 1445 el rey propone a don Lope que ocupe la sede compostelana, aunque finalmente es promovido el día 7 de abril al obispado de Cuenca. Las razones que movieron a Barrientos a aceptar esta diócesis quizá se deban al deseo suyo y del rey de controlar a Diego Hurtado de Mendoza, que aglutina en la ciudad a algunos nobles rebeldes ${ }^{13}$, y de mantener a raya a Pacheco en unas tierras en las que don Juan poseía la población de Belmonte, y sobre todo porque cinco meses más tarde éste será obsequiado con el marquesado de Villena, una concesión que seguramente ya se estaba fraguando. La enemiga entre el valido y el prelado continuará durante toda la vida de ambos, y así a finales de marzo de 1465 el anciano obispo cuando se dirigía a Cuenca es apresado por agentes del marqués de Villena y encarcelado en la fortaleza de Belmonte ${ }^{14}$. En ese momento el obispo permanece fiel a Enrique IV, aunque ya actúe muy en segundo plano, y quedará retenido en el castillo durante un año, por lo que debió de ser en su cautiverio cuando tendría noticias de la llamada farsa de Ávila (5 de junio de 1465).

Dicha enemistad se traslada al ámbito del obispado de Cuenca, en donde Barrientos crea una camarilla particular a la que dispondrá frente a las temidas

\footnotetext{
${ }^{12}$ Sobre la vida de Barrientos: Á. MARTínez CASADO, Lope de Barrientos. Un intelectual en la corte de Juan II, Salamanca 1994, 344 pp.

13 J. DíAZ IBÁÑEZ, «Las relaciones Iglesia-Nobleza en el obispado de Cuenca», en En la España Medieval, 20 (1997), p. 289.

14 Á. Martínez CaSADo, Lope de Barrientos. Un intelectual en la corte de Juan II, pp. 77-79. 
maniobras pachequistas de interferir en la propia curia diocesana. En medio de las luchas civiles de esos años centrales del siglo XV el obispo se gana el apoyo de los Hurtado de Mendoza, un linaje que durante toda la centuria se cuidará de tener miembros en el cabildo catedral conquense ${ }^{15}$.

Por otra parte, don Lope también intenta con decididos esfuerzos acabar con la vieja costumbre de los señores y las autoridades de las villas del arcedianazgo de Alarcón, que solían retener con violencias y coacciones los diezmos recaudados para la mesa capitular de Cuenca. Ya a principios de 1445, unos días antes de ser nombrado obispo de Cuenca y en medio de una situación política extremadamente conflictiva en el reino, los concejos de Alarcón y del Castillo de Garcimuñoz habían vuelto a interferir e incautarse de las rentas decimales del cabildo. Esta práctica, que ya se reveló bajo los señoríos de don Juan Manuel y de Alfonso de Aragón, probablemente no desapareció en los periodos de realengo, pues ahora se vuelve a reproducir de manera idéntica. En consecuencia, el obispo de Cuenca -todavía don Álvaro de Isorna- presentó queja al príncipe por los citados abusos. Don Enrique mandará a los oficiales de ambos concejos que no impidan a los colectores del cabildo sacar sus derechos diezmales, prohibiéndoles asimismo que arrienden dichas rentas a bajo precio mediante coacciones. A su llegada a la sede conquense, dado que el problema continúa, don Lope expone en sus constituciones sinodales de 1446 que las autoridades civiles acosan a los recaudadores del cabildo «poniendoles e faziendoles e conminandoles sobre ello grandes penas e terrores e amenazando e prendiendo e injuriando e feriendo e dannando a los que van o enbian a demandar e arrendar e cojer e sacar los dichos diezmos». Poco después, en agosto de 1452 el obispo Barrientos recibe de Nicolás V facultad para poder legislar contra esta costumbre, por lo que un año después promulga un estatuto contra los usurpadores civiles de rentas eclesiásticas ${ }^{16}$. La medida surtió efecto ya que durante la etapa de don Juan Pacheco al frente del marquesado de Villena no vuelve a detectarse esta práctica.

Para hacer posible la creación de la colegiata, Juan Pacheco elevó una súplica al papa Pío II en el que le exponía la necesidad de que hubiera una iglesia de tales características en la villa de Belmonte; pero como el marqués deseaba ante todo menoscabar el poder de Barrientos, solicitará al pontífice que la iglesia de Cuenca no intervenga en el proceso canónico de erección y que sea el obispo de Burgos, don Luis de Acuña, quien ejecute la bula apostólica. La citada reforma de la cabecera de la parroquia en 1456 allanó el terreno a Pacheco en Roma para lograr sus objetivos, y así solicitó autorización pontificia para la modificación estatutaria y organizativa de la iglesia de San Bartolomé, argumentando la

15 J. DíAz IBÁÑEZ, «Las relaciones Iglesia-Nobleza en el obispado de Cuenca», pp. 294-295.

16 Ibidem, pp. 284-285. 
falta de templos colegiales en todo el obispado, y exponiendo al mismo tiempo la idoneidad de la villa de Belmonte para acoger uno de ellos.

Tras examinar el promotor las rentas que podría destinar para el mantenimiento de su empresa, convino en sugerir la futura composición de oficios y prebendas. Hasta entonces la estructura beneficial de la parroquia era de un cura -con el título de vicario de Belmonte y con jurisdicción de justicia eclesiástica-, tres beneficiados simples y un préstamo, mientras que la proyectada colegiata quedaría compuesta de un prior, un chantre y un tesorero, como únicas dignidades, a las que se agregarían seis canónigos, cuatro racioneros y cuatro medios racioneros, también llamados capellanes $^{17}$. Con esta composición, el marqués conseguía reunir cerca de sí a un conjunto de clérigos que en general pertenecientes a la oligarquía regional, de modo que a través de la Iglesia lograba estrechar lazos políticos y clientelares. Desde mucho tiempo atrás las colegiatas se habían convertido en lugares de destino de varones «sobrantes» de familias nobles (lo mismo que sucedía con los monasterios en relación con las mujeres) ${ }^{18}$. No iba a ser distinto el panorama en La Mancha oriental.

Una vez aceptada la petición del noble, el 1 de diciembre de 1459 el papa Pío II emite en Mantua la bula «Ex Superbe Providentia Maiestatis» mediante la cual aprueba la erección de la colegiata de San Bartolomé de Belmonte a partir de la parroquial y con la estructura expresada. Dadas sus tormentosas relaciones con Lope de Barrientos, Juan Pacheco realizó las gestiones al margen de la diócesis, e involucró en sus iniciativas a don Luis de Acuña, obispo de Burgos, razón por la cual el pontífice se dirigió a este prelado a fin de que instituyese canónicamente la colegial. Cuando por fin se hubo conseguido la ansiada bula de erección, don Luis de Acuña ya pudo respirar tranquilo y se limitó a hacer una consagración honorífica en Valladolid el día 24 de marzo de 1460. Los motivos que llevaron a Juan Pacheco a buscar la mediación del obispo de Burgos estribaban no sólo en la enemistad manifiesta existente con respecto a Barrientos, sino también en el hecho de que don Luis era sobrino del propio marqués. Alegando que Belmonte estaba «en lugar distante», Acuña, acaso incomodado por la misión y consciente de haber cumplido con ella, subcomisionó la tarea de consagración apostólica del templo como colegiata al canónigo de la catedral de Cuenca y abad de Santiago, don Ruy Gómez de Anaya, previo consentimiento, sin duda a regañadientes, del prelado Lope de Barrientos ${ }^{19}$.

A pesar de promover, gestionar la creación de la colegiata y dotarla económicamente, don Juan Pacheco no solicitó el derecho de patronato ni el de pre-

\footnotetext{
${ }_{17}$ BNE, Mss 13124, f. 161r; APB, Bulas, s.n .

${ }_{18}$ G, DuBy, El caballero, la mujer y el cura, Madrid 1982, p. 222.

${ }^{19}$ L. AndúJAR Ortega, Belmonte, cuna de fray Luis de León, p. 63; J. DíAz IbáÑEz, Iglesia, sociedad y poder en Castilla, pp. 277-278.

Hispania Sacra, LX

121, enero-junio 2008, 95-130, ISSN: 0018-215-X
} 
sentación de clérigos; es decir, renuncia a ejercer cualquier influencia directa en la gestión de la iglesia, en un gesto de aparente modestia cuyas razones no resultan fáciles de adivinar, y que posiblemente estuvieran encaminadas a que la Iglesia de Cuenca no pusiera objeciones legales en la constitución de la colegial. Pacheco además conoce perfectamente que tanto el obispo como muchos componentes del cabildo catedralicio desconfían de su proyecto eclesiástico, y por esta razón el 27 de noviembre de 1460, se apresura a hacerles promesa de no solicitar en lo sucesivo a la sede pontificia ningún privilegio que pudiese menoscabar la potestad del clero capitular. Este juramento es probablemente exigido por el cabildo de Cuenca, que pretende que el marqués no demande al papa que le conceda el derecho de presentación de los clérigos de Belmonte. Tras estas promesas de Pacheco y después de haber recibido información oficial de la empresa -su solicitud al papa, la bula pontificia y su contenido, más la consagración canónica de Acuña-, los clérigos fingen aceptar y obedecer de buen grado las letras y decisiones apostólicas y todo lo relativo a la iglesia de San Bartolomé, añadiendo que "es en augmento del cultu (sic) diuino e en honor de la sede episcopal». Así pues, el día 4 de diciembre formularán su solemne aprobación y reconocimiento de la colegiata. El fundador envió para la ocasión a Pedro Fernández de Solis, administrador perpetuo del monasterio de Párraces, en Segovia. Se garantizaba así de forma nominal el sometimiento de la nueva fundación «seglar e collegial» al obispado de Cuenca ${ }^{20}$.

Asimismo Gómez de Anaya fue designado para redactar los estatutos que regirían el funcionamiento de la nueva iglesia colegial, y que indudablemente se elaborarían bajo el dictado del marqués de Villena. Como es natural, regulaban las competencias de cada oficio, el reparto de prebendas o las condiciones de ingreso en el cuerpo capitular. Establecían, por ejemplo que cuando algún clérigo hiciera ingreso y toma de posesión en el colegio, el «paguero», administrador o notario debía recibir como honorarios diferentes cantidades en función del cargo del nuevo componente ${ }^{21}$. También según la normativa, las tomas de posesión de los oficios debían tener lugar ante todo el cuerpo de capitulares, convocado por el portero -encargado de llamar a los clérigos capitulares a sus reuniones-. Si faltara algún componente, la posesión no tendría efecto, pues se requería la unanimidad de los colegiados para llevar a efecto la renovación de

${ }^{20}$ El marqués se dirige a la Iglesia de Cuenca el 4 de diciembre de 1460 en estos términos: «prometo e seguro de no procurar de la Sede Apostolica graçia, indulgençia, rescripto nin bulla alguna que tienda en derogaçion de la dinidad episcopal, nin de los derechos e rentas de vos, el dicho señor obispo, e de vos, los dichos señores dean e cabildo, e de los benefiçiados de la dicha eglesia (...) saluo sin interuenir expreso consentimiento de vos.» (Archivo de la Catedral de Cuenca, Actas Capitulares 1460 , ff. 151r-152r)

${ }^{21}$ Se debía abonar al administrador 200 maravedíes si el ingressandum era dignidad, 150 si recibía canonjía, 100 si el neófito era racionero, y dos reales si fuera capellán. 
prebendados, lo que aseguraba de este modo la cohesión y en principio evitaba la formación interna de bandos y conflictos de poder. Una vez admitido el nuevo miembro, se determina que "pague ante de todas cosas e antes que prinçipie la residençia una comida a todo el colegio o veynte reales para pro del cabyldo, e a de pagar las lauores e carreras segund por el cabyldo fueren tasadas e que vaya a la comida el letrado del colegio»22. Estos eclesiásticos podrán arrendar su oficio a terceros, como sucede en 1502 con Pedro Álvarez de la Plata, clérigo de la diócesis de Salamanca, que disfrutaba de media ración en Belmonte, pero que arrienda su cargo sobre las rentas de dicha media ración o capellanía, a Sebastián de Castro, por un plazo de nueve años a cambio de mil seiscientos maravedíes anuales que Castro debía hacer llegar a la residencia salmantina del capellán titular ${ }^{23}$.

La normativa estatutaria contempla que la nueva colegiata reciba los privilegios acostumbrados en las demás iglesias colegiales y en especial en la más próxima del reino de Castilla, que en el momento de su erección es la iglesia de Santa María de Talavera (convertida en colegiata en 1211). Por esta razón, cuando surjan graves problemas a propósito de las injerencias del cabildo de Cuenca, los clérigos de Belmonte pedirán a sus colegas talaveranos copia de sus privilegios.

Por otra parte la bula fundacional emitida por Pío II establece que la iglesia de San Bartolomé sea progresivamente provista de las rentas de beneficios, préstamos y porciones prestimoniales que fueran quedando vacantes en otras parroquias pertenecientes a los dominios del marqués en las diócesis de Cuenca y de Cartagena. La cuantía de los beneficios no podría superar las cincuenta libras tornesas anuales, y cada uno de los beneficios, préstamos y porciones se irían incorporando conforme fuesen quedando vacantes ${ }^{24}$. Sin embargo, las rentas beneficiales que fueron incorporadas en realidad se circunscribieron tan sólo a la diócesis de Cuenca, pues probablemente la Iglesia de Cartagena supo hacer valer sus derechos para no perder rentas, o acaso Juan Pacheco pudo haber influido a la hora de decidir qué beneficios debían ir siendo anexados a Belmonte. Además, tras la guerra civil los dominios de su hijo Diego en el obispado murciano se redujeron al arciprestazgo de Jorquera, en el que tal vez no hubo beneficios vacantes en la época en que fueron incorporadas las mencionadas rentas eclesiásticas a la colegial de Belmonte.

Por último, una vez alcanzadas las cincuenta libras de renta beneficial, todavía se integrarán a la mesa colegial algunos beneficios procedentes de otras iglesias. Esto sucede cuando los clérigos titulares de esas otras parroquias tu-

${ }^{22} \mathrm{APB}$, Siglos $X V-X V I$, s.n (s. f.).

${ }^{23} \mathrm{APB}$, Bulas, s.n ${ }^{\circ}$ (Toledo, 23-mayo-1502).

${ }^{24} \mathrm{APB}$, Carpeta de bulas, $\mathrm{n}^{\circ} 6$.

Hispania Sacra, LX

121, enero-junio 2008, 95-130, ISSN: 0018-215-X 
vieran a bien ceder el beneficio a la colegiata, previa licencia apostólica. De este modo, algunos componentes de la iglesia de Belmonte disfrutaban simultáneamente de beneficios o préstamos en otros templos y llegado el momento decidían traspasarlos a la colegial inducidos por sus compañeros de cabildo o por el marqués. Así sucede con medio préstamo de Villarrobledo, que, pese a hallarse dentro la diócesis de Toledo y fuera del marquesado pasa a la colegiata por cesión de su titular. Se trata, por tanto, de un método de incorporación de rentas que complementa las condiciones iniciales de financiación.

Pero pese a la dotación económica y suponemos que cierta euforia inicial del clero de Belmonte, se detecta en éste una cierta desidia en los aspectos ceremoniales. Sabemos que en el momento de la concesión del reglamento, Ruy Gómez de Anaya dio treinta años de plazo para que los capitulares se hiciesen con capas de coro con las que acudiesen a los oficios divinos, tal y como se hacía en Cuenca. Sin embargo, en 1491, habiéndose cumplido ya el margen concedido, los clérigos de San Bartolomé solicitarán al abad de Santiago, también llamado Ruy Gómez de Anaya, una moratoria para poder adquirir tales capas ${ }^{25}$.

\section{EL PRIOR}

En cuanto a la estructura de la colegiata, el prior es su máxima autoridad. El primer clérigo que ostenta este rango debió de ser el cura de la iglesia parroquial antes de su transformación, lo cual facilitaba el cambio de manera no traumática. Se trata de Fernando Sánchez de Cuenca, un clérigo instruido -bachiller en Leyes-, generalmente ausentado de la villa a la vista de los sucesivos tenientes de prior con que nos encontramos en las fuentes. Además el fallecimiento de dicho eclesiástico en 1482 no tiene lugar en Belmonte, sino que los colegiales tienen conocimiento de su muerte como «notiçia». En cualquier caso, cuando Fernando Sánchez fallezca, el beneficio curado que poseía en la iglesia de San Bartolomé pasará a engrosar las arcas de la mesa capitular.

El procedimiento mediante el cual este primer prior es designado garantiza la neutralidad del marqués promotor ante el riesgo de que pudiera manejar a su antojo al cuadro de clérigos. De hecho el propio Sánchez de Cuenca no debió de mantener precisamente buenas relaciones con Juan Pacheco, puesto que en 1464 figura jurando con Barrientos su apoyo al rey Enrique IV en un momento en que la liga nobiliaria encabezada por Pacheco presenta su máxima pujanza. Pero quizá fue esta circunstancia de tener como párroco en su villa de residencia a un clérigo del círculo de Lope de Barrientos lo que pesó en el ánimo del

25 APB, Caja siglos XV-XVI, s.n (Cuenca, 30-noviembre-1491). Dicho capitular hizo posible el aplazamiento por un término de dos años. 
marqués para instituir la iglesia colegial. Con ella podría ejercer un mayor control sobre la clerecía de esa parte del marquesado, que de este modo quedaría fuera de la órbita del prelado enemigo, y además establecería un contrapeso al poder del obispado en la comarca. Por esta razón, más adelante parece que los rectores de la colegial estarán más próximos al señor de Villena.

En efecto, Diego de Iniesta, el segundo prior, será un clérigo de especial importancia en el señorío y en el obispado de Cuenca. Lo primero que nos llama la atención de su figura es que en un cuaderno sin numerar conservado en el Archivo Parroquial de Belmonte es denominado «Diego Pacheco» en un contrato de 1491, un dato que suponemos muy difícil que pueda constituir un error de escribano $^{26}$. Esto nos ha llevado a sospechar que este personaje pertenecía a la propia familia del marqués de Villena, acaso por vía de bastardía, algo que podría explicar algunas maniobras que parecen coordinadas por ambos. Lo que también parece seguro es que perteneciera a la familia de Juan Sánchez de Hinestrosa, dueño de la heredad de Tresjuncos a mediados del siglo XV que casó con Teresa Sánchez de Iniesta.

Es importante recalcar el hecho de que el prior como director de la iglesia asume el cargo de vicario, una autoridad que antes de la creación de la colegiata ejercía el cura de la parroquia de San Bartolomé. A partir de la remodelación de la estructura de la iglesia, el párroco pierde la potestad de la justicia eclesiástica en la villa, que pasará al obispo de Cuenca, mediante una transferencia jurisdiccional que debió de facilitar la aceptación de la nueva colegiata por parte del clero catedralicio. Tal vez como consecuencia de la pérdida de atribuciones jurisdiccionales, el oficio de arcipreste de Alarcón, que si parece que retiene este tipo de competencias, queda anexado al priorazgo de Belmonte. Creemos que tal asimilación se consigue cuando Diego de Iniesta -quien ya ejercía como arcipreste en Alarcón- suceda a Sánchez de Cuenca en la dirección de la colegiata, pues es en 1483 cuando ya hallamos que ambos cargos recaen sobre dicha persona ${ }^{27}$.

Como segunda contrapartida a la merma de atribuciones, el prior de Belmonte se convierte en miembro del cabildo de la catedral de Cuenca, circunstancia encaminada a facilitar la coordinación de la vida diocesana, a la vez que sirve al director de la colegiata para que pueda defender con más facilidad los derechos de su iglesia en la capital episcopal. Pero la simultaneidad de estas funciones también puede constituir un peligro para Belmonte debido al riesgo de distanciamiento de su director o a las tentaciones que éste puede recibir por el cabildo catedralicio en menoscabo de la tendencia al régimen autónomo de

${ }^{26}$ APB, Censos, cuaderno s.n ${ }^{\circ}$ (s.f., f. 8r).

27 APB, Carpeta de bulas, $\mathrm{n}^{\circ} 13$ (22-mayo-1483). Diego de Iniesta era en 1473 tesorero de la colegiata y arcipreste de Alarcón: APB, Censos, s.nº (Belmonte, 30-mayo-1473).

Hispania Sacra, LX

121, enero-junio 2008, 95-130, ISSN: 0018-215-X 
las instituciones eclesiásticas de la villa de Belmonte. En efecto, el prior de la colegiata, como capitular disfruta de prebendas en otras iglesias de la diócesis así como de algunos bienes materiales. En concreto, el cabildo facilitó al prior Iniesta unas casas en Cuenca como vivienda particular, al igual que una heredad en Albaladejo del Cuende, y podemos sospechar que esta entrega ocasionaría cierta dependencia del clérigo de Belmonte con respecto del cabildo ${ }^{28}$.

\section{LA ANEXIÓN DE BENEFICIOS Y LOS CONFLICTOS CON LA CATEDRAL DE CUENCA}

Mientras viva, el obispo Lope de Barrientos empleará todo tipo de maniobras a fin de neutralizar el régimen administrativo y económico independiente alcanzado por la colegiata manchega. El prelado intenta motu proprio proveer hacia 1466 algunas capellanías (o medias raciones), contraviniendo las condiciones establecidas por el propio pontífice. Aunque el marqués se opuso a ello, Barrientos siguió insistiendo, si bien con escaso éxito ${ }^{29}$.

La autonomía de esta iglesia se mantendrá bajo la atenta vigilancia de Juan Pacheco, quien en 1469 reglamenta con detalle los oficios de difuntos y las capellanías, exhortando a que no se entrometa en ellos ningún obispo ni otros eclesiásticos, salvo los pertenecientes a la colegiata. En 1467 Pacheco había sido nombrado maestre de la Orden de Santiago, y aunque debe renunciar a su título de marqués de Villena en la persona de su hijo Diego (5 de abril de 1468), seguirá ocupándose de sus asuntos en los señoríos de la familia, y concretamente de los proyectos religiosos de su villa de Belmonte, al menos hasta el fallecimiento de Barrientos (1469).

En 1469 Juan Pacheco firmará un pacto con el legado pontificio Antonio Jacobo de Veneris a fin de fiscalizar la diócesis conquense. Veneris había acudido como nuncio a negociar la paz entre los nobles y el rey, y aunque en un principio fracasa y es humillado por Pacheco, finalmente este se gana su confianza ${ }^{30}$. El italiano garantiza al marqués el control sobre algunos castillos, mientras el de Villena asegura su apoyo al eclesiástico para convertirlo en obispo de Cuenca tan pronto como sea posible, en evidencia de la avanzada edad de Barrientos ${ }^{31}$.

En efecto, ese mismo año don Lope muere en la ciudad de Cuenca. El cabildo, dominado por los Hurtado de Mendoza, declarados enemigos de Pacheco,

\footnotetext{
${ }^{28}$ A la muerte de Iniesta, en 1503, el cabildo sacó a subasta la casa que había ocupado en Cuenca.

${ }^{29}$ APB, Poderes, s. n'.

$30 \mathrm{~J}$. TORRes Fontes, El príncipe don Alfonso y su itinerario. La contratación de Guisando (1465-1468), Murcia 1985, p. 91.

${ }^{31}$ En las negociaciones entre Pacheco y Veneris, éste promete el arcedianazgo de Calahorra para un hijo de Pacheco.
} 
intentó hacer valer su independencia frente a las injerencias foráneas. Los capitulares elegirán a Juan de Hurtado como prelado sucesor, haciendo incluso frente a los esfuerzos del papa por imponer al candidato pachequista, cuyo partido acabó triunfando merced a la insistencia del marqués para que el débil rey Enrique IV elevase al papa la súplica para trasladar a Antonio de Veneris al obispado conquense ${ }^{32}$. Por consiguiente la permanencia de Veneris en el episcopado de Cuenca (1469-1479), garantizará tanto a Juan Pacheco como a su hijo y sucesor, Diego López Pacheco, cierta tranquilidad en cuanto a que la iglesia diocesana no intervendría en las iglesias de su señorío manchego.

Pero la llegada de Rafael Riario, cardenal de San Jorge y sobrino de Francesco della Rovere (Sixto IV), al obispado conquense en 1493, cambiará por completo la relación de la Iglesia de Cuenca con la colegiata de Belmonte. Tras su nombramiento como obispo, Riario envía a la península Ibérica a un grupo de hombres de negocios italianos encargados de recaudar para él las rentas episcopales y canalizarlas a través del puerto de Valencia, ciudad en la que se hallan afincados numerosos genoveses que facilitarían la saca de monedas hacia Italia. Uno de estos hombres es Pedro de Costa, amigo personal del cardenal de San Jorge, que será nombrado por éste provisor y vicario general del obispado de Cuenca inmediatamente a su propia designación como obispo de la diócesis. Una vez en Cuenca, Costa se convierte en el hombre de confianza del obispo y gobierna con carta blanca la diócesis en nombre del cardenal, permitiendo a sus paisanos los más variados atropellos como recaudadores eclesiásticos y como clérigos, dejándoles apropiarse de todo tipo de rentas y beneficios eclesiásticos ${ }^{33}$.

El cobro de rentas episcopales y la captación de beneficios capitulares y parroquiales acaban repercutiendo en el gobierno eclesiástico de las tierras del marquesado, y en especial donde se concentra más poder y riqueza: la colegiata de Belmonte. Los principales implicados en la trama son, como veremos, Agustín de Spínola y Jacobo Cardello, oportunamente amparados por el cardenal Riario y el provisor Costa.

Así pues, las relaciones establecidas entre Juan Pacheco y los sucesivos obispos de la sede conquense servirán de marco de las acciones del primero a la hora de llevar a cabo su particular política religiosa en su señorío, y en particular en relación con la transformación de la iglesia parroquial de Belmonte en colegiata. Con este hecho, la villa del marquesado pasaba a emular-mutatis

32 S. T. NALLE, God in La Mancha: Religious Reform and the People of Cuenca. 1500-1650, Baltimore 1992, p. 9.

${ }^{33}$ Sobre este fenómeno, Cfr.: M. Diago Hernando, «El cardenal de San Jorge y los hombres de negocios genoveses en Cuenca durante el reinado de los Reyes Católicos», en Espacio, tiempo y forma. Serie III. Historia medieval, 10 (1997), Madrid, pp. 137-155.

Hispania Sacra, LX

121, enero-junio 2008, 95-130, ISSN: 0018-215-X 
mutandis- las ciudades episcopales, lo que venía en claro detrimento y desafío de la iglesia conquense.

Otro aspecto fundamental en la puesta en funcionamiento y en la posterior evolución de la colegiata es su sostenimiento económico, que debía ser necesariamente muy nutrido a fin de mantener a todos los prebendados y acólitos de la iglesia, más su personal seglar. La financiación se basa en tres tipos de enajenación de renta: la dotación directa por parte de la familia Pacheco, la anexión de beneficios y las aportaciones particulares efectuadas a modo de limosna por habitantes de toda la comarca, a cambio de misas y otros servicios litúrgicos. Un detenido seguimiento de estas tres formas de financiación clarifican notablemente los problemas que surgen entre el clero local, el catedralicio, el obispo y los señores de Villena en torno al control de las distintas rentas y al gobierno de la iglesia de Belmonte.

No sabemos en cuánto se fijó la cuantía de la asignación material destinada inicialmente por Juan Pacheco. Las letras pontificias hablan de que el marqués destinó setenta florines anuales ${ }^{34}$. Pero por otra parte se establece un montante monetario adicional cuando el promotor decida fundar y costear unas misas de aniversario, y para ello hace renuncia y cesión de un juro de heredad de veinticinco mil maravedíes destinados todos los años a la colegial a partir de la fundación de estas memorias. Estos réditos procedían de una renta concedida por un privilegio otorgado por el rey Juan II (confirmado por Enrique IV) de ciertos derechos obtenidos en los sexmos de Arcas y Altarejos, y que Pacheco, siendo ya maestre de Santiago, desvió hacia los clérigos de Belmonte al objeto de que oficiaran algunas misas y aniversarios «perpetuamente en la dicha yglesia por las animas de <sus abuelos e padre e madre del dicho maestre e por sus animas de el> e de la marquesa su muger, quando a Dios quando a Dios (sic) pluguiere de los llevar» 35

A las misas -instituidas por medio de una escritura de 29 de marzo de 1469debían asistir todos los componentes de la iglesia colegial, y con carácter voluntario todos aquellos vecinos de Belmonte que, aun sin oficiar en San Bartolomé, tuvieran órdenes sagradas. A éstos se les daría de pitanza cinco maravedíes en las celebraciones comunes de los viernes, y diez maravedíes cuando acudieran en las fiestas principales con su vigilia de vísperas. Cuando el maes-

\footnotetext{
${ }^{34}$ BNE, Mss 13124, f. 161r-v.

35 AGS, Mercedes y Privilegios, leg. 15, n 37, ff. 421-425. Los oficios consistían en dos misas diarias rezadas, a saber: los viernes, misa de la Pasión; sábados, de Santa María, y los demás días de la semana, tal como se acostumbraba a hacer en la catedral de Cuenca. Al término de cada misa un clérigo rezaría un responso encima de las tumbas, a las que rociará con agua bendita. Asimismo, cada viernes habría de celebrarse otra misa cantada, seguida de su correspondiente responso. Don Juan Pacheco dejará dispuestos otros oficios concretos por su alma y por las de sus cuatro referidos antepasados.
} 
tre reglamente de manera pormenorizada todos los citados oficios de difuntos y sus capellanías, exige que «non se entremetan nin tengan que fazer obispo ni arçobispo ni otro perlado ni persona eclesyastica alguna salvo los sobredichos clerigos del dicho colegio». Esta advertencia ilustra el deseo de que en sus ceremonias no se vean implicados clérigos ajenos a la colegiata, o dicho de otro modo, eclesiásticos que no estuvieran bajo la órbita e influencia de la familia Pacheco. Es por entonces cuando don Juan atraviesa una etapa caracterizada por un amplio margen de maniobra y utiliza sus habilidades para conseguir instalar a Veneris en el obispado de Cuenca.

Sin embargo, los problemas se cernirán continuamente sobre los Pacheco habida cuenta de la enemiga que les profesa una parte significativa del clero capitular conquense, que moverá todos sus resortes para intentar acaparar en su provecho algunas rentas beneficiales de la colegial, al mismo tiempo que pretenderán neutralizar el enorme poder acumulado por aquéllos en el terreno eclesiástico comarcal. Por eso la caída en desgracia del linaje pachequista a raíz de la guerra civil jugará en favor del cabildo de Cuenca que irá ganando parcelas de dominio sobre Belmonte. En este sentido, no podemos pasar por alto la estrecha colaboración existente entre los Reyes Católicos y una parte del clero catedralicio, en especial el arcediano de Alarcón, Gabriel Condulmario.

En pleno proceso de normalización de relaciones políticas y personales una vez concluida la guerra en Castilla, el 20 de mayo de 1480 los Reyes Católicos confirmarán a Juan Pacheco el privilegio de sus derechos sobre sus rentas en los sexmos de Arcas y Altarejos, lo que viene a ser también una ratificación civil de sus memorias de aniversario. Este reconocimiento vendrá a complementarse con las disposiciones aprobadas en las Cortes de Toledo celebradas ese mismo año, en las que se sancionó que quienes tuvieran juros de heredad pudiesen enajenarlos a terceros, circunstancia que aprovechará más tarde Diego López Pacheco para transferir a la mesa capitular de Belmonte otro sustancioso juro.

Pero en realidad las ulteriores dotaciones que emprendió Diego López Pacheco vendrán planteadas en buena medida como maniobra para contrarrestar las estrategias de la Iglesia de Cuenca a fin de inmiscuirse en el gobierno de la colegial de San Bartolomé. Desde su declive personal a propósito de su participación en la guerra civil dentro de las filas de «la Beltraneja», don Diego no hará más que perder terreno en el control de la colegiata. La más evidente constatación de esta realidad viene dada por la creación de una maestrescolía en la iglesia de San Bartolomé como nueva dignidad por parte del papa Inocencio VIII (1484-1492) para adjudicarla al clérigo Diego García de Guadalajara a instancias del mismo. Esta maniobra se efectúa en contra de lo dispuesto por las bulas y demás escritos fundacionales, y frente a los deseos de los clérigos colegiales y del marqués, aun a pesar de que los Guadalajara 
constituyen un linaje asentado en Belmonte que contará con diversos clérigos dentro de la colegiata ${ }^{36}$.

Tras la muerte de García de Guadalajara, el cardenal Rafael Riario, a la sazón obispo de Cuenca, designa hacia 1499 por medio de su vicario general y provisor a Gómez Carrillo como nuevo maestrescuela. Tal nombramiento venía a suponer una violación del derecho de presentación que el marqués de Villena había negociado en la Santa Sede con respecto a los clérigos de la colegiata. Sin embargo, en este momento la iglesia de Belmonte atraviesa su momento de mayor intervención por parte de Cuenca, y sus miembros se ven obligados a aceptar a Carrillo como nuevo compañero, aunque después aleguen que le dieron el oficio sin perder su derecho a quitárselo.

Así pues, para retomar el control sobre la iglesia colegial, Diego López Pacheco intenta conseguir de Roma la concesión del derecho de patronazgo, principalmente porque lleva anejo el auténtico resorte para ejercer el poder sobre la clerecía desde fuera, y que es el citado derecho de presentación, que tal vez ya había recibido, pero que en este caso era desatendido sistemáticamente por las autoridades diocesanas ${ }^{37}$.

Aprovechando quizá cierta amistad con Alejandro VI, elegido papa en 1492, López Pacheco se había dirigido a Roma para informar y denunciar lo que a su juicio eran abusos cometidos por el cabildo de Cuenca sobre la iglesia de Belmonte e indirectamente contra su propia persona, y para reclamar el patronato sobre la colegiata alegando en su favor que en fecha reciente la ha dotado con nuevos fondos. Asimismo indica al pontífice que ha procedido a aumentar la dotación de la colegiata con cuatrocientos florines. Una vez hechos los trámites, Rodrigo Borja se dirige a la Iglesia conquense para dar cuenta de la nueva asignación y para exigir a los capitulares que concedan al marqués el patronazgo de la colegial y el derecho de presentación sobre todos los oficios prebendados, lo que en definitiva era el objetivo principal del marqués en la elevación de su queja. La letra apostólica se tendrá que complementar con dos bulas pontificias: una en la que Alejandro VI ratifica las cartas fundacionales salvo ciertas cargas y defectos observados; y la otra, de 9 de octubre de 1501, por la que se confirma al marqués los derechos de patronato y de presentación frente a las arrogaciones del clérigo genovés Agustín de Spínola, provisor y vicario general de Cuenca -y futuro arcediano de Alarcón-, y de Francisco Hurtado de Mendoza, deán de la catedral, señalando el papa en su escrito que estas dignidades no procedieron a respetarle los mencionados privilegios. En prosecución del otorgamiento de sus derechos al marqués, Alejandro VI expide otra bula nombran-

\footnotetext{
${ }^{36}$ APB, Siglos XV-XVI, s. no (Belmonte, 31-agosto-1502).

37 Idem.
} 
do como garantes de lo contenido en las letras pontificias emitidas a tal respecto, al maestrescuela de Toledo y al vicario general de $\mathrm{Cuenca}^{38}$.

Gracias a esta respuesta y otras bulas del papa valenciano, Diego López Pacheco de momento recupera $-\mathrm{y}$ con creces- el poder perdido en su particular cuasi-catedral. En consecuencia consigue apartar dejar sin efecto la designación de Gómez Carrillo como maestrescuela de Belmonte, cuyo nombramiento había impugnado con el apoyo de los demás clérigos de Belmonte, con quienes el marqués actúa unido en un frente común. Pacheco, adelantándose a cualquier actuación del cabildo de Cuenca, forzará una política de hechos consumados y en 1502 pedirá a los hombres de la iglesia de San Bartolomé que nombren a su capellán Luis de Belmonte como maestrescuela, frente a lo determinado en su día por el absentista obispo Riario, pretendiendo así recuperar el poder perdido. De este modo, aprovecha en favor de su capellán la irregular creación de la dignidad en litigio ${ }^{39}$.

Pero este derecho de presentación conseguido por don Diego no es aplicable a los beneficios simples servideros y al préstamo que existían en la iglesia de San Bartolomé y que continúan existiendo tras su transformación en colegiata. Aprovechando esta situación, Jacobo Cardello, paisano y amigo de Agustín de Spínola, se hará dotar de uno de los beneficios simples existentes en la propia iglesia de Belmonte, lo que propiciaba que el clan de los genoveses ejerciera un mayor control sobre la colegial. Esta maniobra de apropiación beneficial, firmemente respaldada por Roma, provocará la reacción del cabildo belmonteño, que entrará en un largo litigio para expulsar de su estructura beneficial a Cardello.

Con este tipo de ardides, la desconfianza de don Diego con respecto al cabildo de Cuenca llega a tal extremo que cuando el cardenal Della Rovere acceda a la silla de Pedro, aquél volverá a solicitar la confirmación de todo cuanto consiguiera de Alejandro VI. Por consiguiente, el 18 de mayo de 1504 Julio II emite una nueva bula por la que se ratifican los derechos del marqués frente a las desobediencias de los citados arcediano y deán; pero le confirma el patronazgo a condición de pagar quinientos ducados para reparaciones y fábrica de la iglesia, y para las prebendas. De esta subrepticia manera el papa contentaba al patrón, pero también beneficiaba a Cardello.

Cabe preguntarse si esta confirmación no habría llegado de no haber don Diego proporcionado entretanto una nueva dotación a la iglesia de Belmonte. Un mes antes de la data del diploma pontificio, el 17 de abril, estando el marqués en Toledo, dicta carta de renuncia y traspaso de un juro cuyo montante asciende a 37.500 maravedíes anuales a perpetuidad, sacados de otro juro de

\footnotetext{
${ }^{38}$ BNE, Mss 13124, f. 161r-v.

${ }^{39} \mathrm{APB}$, caja siglos XV-XVI, s. $\mathrm{n}^{\circ}$ (Belmonte, 31-agosto-1502). El cardenal Rafael Riario nunca pisó la diócesis de Cuenca.

Hispania Sacra, LX

121, enero-junio 2008, 95-130, ISSN: 0018-215-X
} 
520.000 maravedíes que el marqués posee sobre las alcabalas y tercias de Cuenca, Huete y sus respectivos partidos. Este juro mayor había sido otorgado al marqués en febrero de 1485 , y ya en un documento de 25 de marzo siguiente se pormenorizará el desglose de las cantidades que Diego López Pacheco habría de cobrar por cada concepto en tierras de Cuenca y de Huete. La parte destinada a Belmonte se extrae concretamente de unas alcabalas que don Diego percibe y son tomadas de las «çerundajas» de la ciudad de Cuenca (por lo que el marqués solicita a los contadores de alcabalas que traspasen en su contaduría los 37.500 maravedíes en favor de la colegiata). Con este acrecentamiento de rentas, el marqués también intenta garantizar ciertos oficios y misas perpetuos que se celebrarían por su alma y por la de su esposa doña Juana ${ }^{40}$.

Don Fernando y una irreversiblemente enferma Isabel de Castilla confirmarán desde Medina del Campo el 14 de septiembre de 1504 al prior y a los colegiales de Belmonte el traspaso del juro en su favor. Así se ratifica el cobro de estas nutridas rentas por parte del cabildo de San Bartolomé, acción que tendrá efecto cada cuatro meses. Con este tipo de operaciones Belmonte -que no la mayoría de sus moradores- compensa la salida de renta agraria desde la población hacia Cuenca en concepto de diezmo pontifical, pues ahora se puede dotar a la iglesia colegial con capital procedente de la ciudad diocesana. Sin embargo, la pugna en torno a esta renta continuará y los clérigos seguirán encontrando resistencias por parte de los agentes fiscales para desviar la alcabala. Esta actitud motivará la elevación de nuevas súplicas de los de Belmonte a la Corona ${ }^{41}$.

Asimismo, Pacheco también enajena otro juro de veinticinco mil maravedíes para el cabildo de Cuenca a fin de que sus miembros continúen oficiando ciertas memorias y aniversarios por el alma de la primera esposa del marqués. Don Diego enviará en noviembre de 1504 a su sobrino Luis Pacheco a Cuenca para que muestre el privilegio real a los capitulares. Desde ese momento el cabildo deberá entenderse con los contadores reales para recaudar los citados maravedíes ${ }^{42}$. Resulta sorprendente que el marqués transfiera una suma tan abultada a un cabildo en el que residen tantos enemigos, pero quizá todo ello se deba a un intento de apaciguar la codicia de los miembros más ambiciosos de la catedral.

Por otra parte, las diferencias entre Belmonte y Cuenca no afectaban sólo al control de la institución, sino también a la intervención del clero catedralicio en

40 Todos los detalles referentes a los citados juros se encuentra en AGS, Mercedes y Privilegios, leg. $15, n^{\circ} 37$, ff. 407-412. No hemos podido verificar qué significa «cerundaja», pero sí sabemos que es una renta que también se venía cobrando en el reino de Murcia.

${ }^{41}$ APB, Siglos XV-XVI, s. n ${ }^{\circ}$ (Belmonte, 5-mayo-1508).

${ }^{42}$ Archivo de la Catedral de Cuenca, Actas Capitulares, 1504, ff. 133v-134r. Luis Pacheco, señor de Villarejo de Fuentes desde 1497, estaba casado con una mujer de la familia de Gabriel Condulmario, arcediano de Alarcón (1475-1500) lo que manifiesta la construcción de clientelas mediante el emparentamiento de eclesiásticos y familias nobiliarias. 
las cuentas de la colegial. Ante todos los atropellos sufridos, el cuerpo de clérigos de la villa enviará en 1491 (recordemos que en plena hostilidad en torno a la provisión de la espuria maestrescolía) al presbítero y mayordomo de la iglesia, Fernán Sánchez de Guadalajara, para que vaya a Talavera a comprobar los estatutos que rigen su iglesia colegial, así como los privilegios recibidos desde su lejana fundación hasta ese momento. Una vez en la villa talaverana, el comisionado presentó un requerimiento, exponiendo al colegio de clérigos que, la iglesia de Belmonte, «al tiempo que de perrochial en colegial fue helegida e criada por el nuestro muy santo padre papa Pio Segundo (...), le fueron dados, conçedidos e otorgados todos los preuillejos, libertades e esençiones de la yglesia collegial mas çercana (...) a la dicha villa de Belmonte». Cuando Sánchez de Guadalajara se presentó ante este lugarteniente del deán de Talavera, le requirió traslado autorizado de los citados privilegios, exenciones y franquezas. Entre los documentos que los contenían se hallaba uno que explicitaba cómo la iglesia de Talavera estaba exenta de pagar diezmos tanto de los heredamientos dotales como de los adquiridos posteriormente, de igual modo que sucedía con los capitulares en relación con sus frutos y rentas, heredamientos y bienes ${ }^{43}$.

Se tomó juramento a varios clérigos de la villa acerca del estado en que se encontraban en Talavera varios de los problemas, fundamentalmente económicos, que acuciaban a sus homónimos belmonteños, tal vez a falta de otros documentos que demostraran con claridad el funcionamiento de las cuentas eclesiásticas. A tenor de la consulta, los diezmos de la villa iban íntegros a la colegiata, sin que tuvieran parte en ellos los canónigos de Toledo; la mesa capitular y fábrica no pagaban ningún diezmo, ni de heredades dotales o antiguas, ni de las adquiridas con el paso del tiempo; la justicia eclesiástica de la villa actuaba en contra de los deudores que la colegiata tuviera, y aplicaba por esta causa excomuniones y entredichos; y finalmente, también se reveló que los canónigos talaveranos que se ausentaban por razón de dirigirse a un Estudio General, tenía derecho a percibir unas cantidades complementarias, lo que puede significar que algún clérigo de Belmonte estuviera en proceso de estudio, y para ello se solicitaba información al respecto.

Aparte de la dotación directa aportada por los Pacheco, otra vía de financiación de la iglesia colegial de Belmonte se materializa mediante la anexión de

${ }^{43}$ APB, Siglos XV-XVI, s.n (Talavera, 23-junio-1491). El documento trataba «sobre rason de la esençion de como el cabildo e mesa capitular de la dicha yglesia collegial de la dicha villa de Talaue$\mathrm{ra}$, ni sus frutos ni rentas ni heredamientos ni otros bienes de la dicha mesa capitular non han pagado nin pagan diesmo ninguno, asy de los heredamientos que antyguamente tienen e poseen como de las que despues han comprado e compran, e les han sydo e son mandadas por algunas personas; e de commo los bienes que los benefiçiados de la dicha yglesia collegial de la dicha villa de Talauera tienen ni de sus frutos ni rentas pagan e van e dan sus diezmos dellos a la dicha yglesia collegial de Santa Maria».

Hispania Sacra, LX

121, enero-junio 2008, 95-130, ISSN: 0018-215-X 
beneficios parroquiales. Entre estos conviene diferenciar tres tipos de rentas beneficiales: los beneficios y capellanías preexistentes en la propia iglesia de San Bartolomé, los anexados en virtud de la bula fundacional y los incorporados por otros métodos. Cuando la parroquia se transforma en colegiata, los beneficios y el préstamo que constituían su estructura económico-pastoral se integran progresivamente a las arcas del cabildo de Belmonte a medida que sus titulares vayan falleciendo. Cuando llegara la luctuosa ocasión los clérigos colegiales irían tomando posesión de dichos oficios, para incorporar sus beneficios a la mesa capitular ${ }^{44}$. De manera semejante se procede cuando se vayan produciendo bajas en las parroquias del marquesado; pero también hemos visto que algunos clérigos preferentemente miembros de la colegiata incorporaban a esta otros beneficios que disfrutaban en otras iglesias, como sucede con el traspaso de media prestamera de la iglesia de Villarrobledo, en el obispado de Toledo. De este modo se anexan otras rentas complementarias distintas a las contempladas en la bula fundacional, y desde este momento el cabildo de Belmonte tendrá la potestad de nombrar en su lugar los clérigos tenientes de beneficiados que oficiarían en esas iglesias con beneficios vinculados a la colegiata.

Con la anexión de estas rentas parroquiales, el marqués aseguraba su control sobre los clérigos de la comarca a través de la iglesia de Belmonte, pero sobre todo conseguía despojar al obispado conquense de influencia sobre la clerecía de su señorío, y además se aseguraba un clero clientelar y un desvío y retención de la renta eclesiástica que se reparte entre este clero colegial necesariamente afín a Pacheco.

En consecuencia, por uno u otro método se anexionarán los siguientes beneficios:

- el beneficio curado de la propia iglesia de Belmonte (1482);

- los tres beneficios simples y un préstamo de la misma iglesia (uno en $1470)^{45}$;

- un beneficio simple en la parroquia de El Pedernoso (1470);

- un beneficio en la parroquia de Santo Domingo de Alarcón (1483);

- otro beneficio simple de la parroquia de Santiago de Alarcón;

- una prestamera -quizá dos- en la iglesia parroquial de Santa María de Monreal;

44 Por ejemplo en 1485, el cabildo de Belmonte tomó posesión de «una capellania fuera de las del numero», que vacó por muerte de Alfonso de Cañete, arcipreste de Rodillas. APB, Caja de poderes, s. $n^{\circ}$ (Belmonte, 16-marzo-1485).

${ }^{45} \mathrm{La}$ anexión de los tres beneficios simples y del préstamo de Belmonte será revocada por el papa Alejandro VI en 1504. 
- un préstamo en la iglesia de la Trinidad de Alarcón (1481);

- medio préstamo en la citada iglesia de Santiago (1482);

- dos beneficios en la abadía de Tresjuncos (1493);

- una prestamera en Las Pedroñeras (1486); y

- media prestamera en la parroquia de Villarrobledo (1487).

La anexión y la conservación de cada uno de estos beneficios siguieron sus respectivas y particulares peripecias, sintomáticas de lo que son las luchas de poder en torno al control y disfrute de las rentas eclesiásticas, sobre las que hay que hacer algunas indicaciones que nos permitan conocer más a fondo cómo se realizan los traspasos y qué conflictos pueden llegar a generar.

Como hemos señalado, el beneficio curado de Belmonte fue incorporado en 1482 a raíz del fallecimiento de su titular, Fernando García de Cuenca, que por su condición de cura rector pasó a ser primer prior de la colegiata. Progresivamente se irán anexando las demás rentas establecidas en la antigua parroquia.

A principios de 1470 fallece Francisco Bordallo canónigo de la catedral de Cuenca y abad de la Sey, a quien creemos de origen portugués. Este clérigo poseía un beneficio simple en la iglesia de Belmonte, que será el primero que se incorpore a la mesa capitular. Por ello el 27 de marzo de 1470 los colegiales toman posesión de dicho beneficio mediante el correspondiente ritual hecho en la parroquia. Pero Bordallo también poseía otros beneficios parroquiales, entre los cuales había uno en la iglesia de Santa María de El Pedernoso, que obviamente también quedó vacante. Así pues, la colegial de Belmonte incorporó a su mesa capitular la renta del mencionado beneficio, aunque debería dejar oficiando como teniente del beneficio de El Pedernoso a otro clérigo, que probablemente fuera el mismo que hasta la fecha venía ejerciendo como asalariado de Francisco Bordallo. Asimismo, el beneficio tenía anexadas ciertas tierras, que el cabildo de Belmonte cederá más tarde en arriendo, obteniendo con ello otros ingresos paralelos ${ }^{46}$.

Cuando en Belmonte se tiene noticia del fallecimiento de Bordallo, el canónigo de la colegial, Fernando de Guadalajara, se dirige a la parroquia de El Pedernoso a tomar posesión del beneficio ante el cura párroco siguiendo el ritual acostumbrado. Sin embargo, hacia 1483 surgió un litigio en torno a este beneficio simple incorporado a Belmonte. El caso se inició ante Pedro de Montealegre, canónigo de Cuenca, como juez ejecutor. Asimismo, el deán de la catedral de Burgos, Alonso de Barajas, actuó como asistente de capitulación para llegar a un acuerdo, pero los capitulares de Belmonte se sintieron agraviados con los términos de dicha capitulación, renunciando a ella, de modo que el pleito aún

${ }^{46} \mathrm{APB}$, Siglos XV-XVI, s.n ${ }^{\circ}$ (El Pedernoso, 27-marzo-1470).

Hispania Sacra, LX

121, enero-junio 2008, 95-130, ISSN: 0018-215-X 
prosiguió hasta que se emitió sentencia favorable a la colegiata, aunque desconocemos los términos de su resolución. En cualquier caso, en Belmonte siguieron disfrutando de la renta beneficial, puesto que en septiembre de 1492 el beneficio fue cedido por el clero del templo de San Bartolomé de forma vitalicia al bachiller Fernando Sánchez de Fresno, con licencia para enajenarlo o subarrendarlo a su vez a terceros. Se hace en recompensa por los servicios que prestó dicho bachiller a la iglesia colegial por sus «muchos seruiçios e buena hermandad» en el tiempo en que ejerció de tesorero ${ }^{47}$.

El beneficio de la parroquia de Santo Domingo de Alarcón se anexó a la colegial en 1483 al fallecer su titular, fray Juan de Ayllón, abad del convento dominico de San Pablo de Valladolid. La posesión de este beneficio también será objeto de conflicto, dado que en 1502 surge cierta oposición en torno a su titularidad entre el cabildo de Belmonte y un clérigo de la diócesis de Zamora llamado Alonso Muñoz de Castañeda. La discordia fue resuelta por Gonzalo Sanz de Hinestrosa -canónigo de Cuenca diputado por el obispo de Lucca, Galeotto Franciotti-, en favor de los clérigos de Belmonte, aunque hemos de advertir cierto parentesco entre este canónigo Hinestrosa y el futuro prior de Belmonte, Diego de Hinestrosa ${ }^{48}$.

Por otra parte, en 1492, el cabildo de Belmonte incorpora dos beneficios pertenecientes a la abadía de Tresjuncos. Por esta razón dos clérigos de Belmonte se integraron en el cabildo de dicha abadía, en virtud de una disposición que acarreó las protestas de algunos clérigos de Tresjuncos, que finalmente resultaron acalladas por el provisor del obispado.

El préstamo de la iglesia de Santa María de Monreal, aldea de Belmonte, fue transferido a la iglesia de Belmonte en 1504 a consecuencia del fallecimiento de su titular, el citado deán de Burgos, Alonso de Barajas. Sin embargo, al quedar vacante la prestamera, el provisor Agustín de Spínola arrebatará a la colegiata este préstamo en su propio provecho, y mandará a un criado suyo para que los dezmeros le den la renta.

Otro beneficio simple de la parroquia de Santiago de Alarcón correspondió ser anexado a la colegial. Cuando en 1504, queda libre con ocasión de la muerte de su titular, el licenciado y canónigo en Cuenca, Juan López de Cigales, el cabildo de Belmonte solicitará al juez ejecutor apostólico, Cristóbal de Illescas, que les asigne el beneficio de la iglesia de Santiago. Así lo cumplió, haciendo solemne entrega del oficio y renta a Juan de Guadalajara, canónigo de la iglesia de Belmonte, y a Diego de La Parrilla, teniente de arcipreste en Alarcón, que

\footnotetext{
${ }^{47}$ APB, Siglos XV-XVI, s.n ${ }^{\circ}$ (Zamora, 21-junio-1483); Bulas, s.n ${ }^{\circ}$ (Belmonte, 29-septiembre-1493). Juan de Morales actuó como procurador de la iglesia de El Pedernoso.

48 APB, Caja de bulas, s.nº (Belmonte, 26-noviembre-1502). Diego de Hinestrosa será el tercer prior de la colegiata de Belmonte.
} 
habían comparecido como procuradores de la colegiata. Por añadidura, la presencia de La Parrilla como procurador confería al acto un carácter más oficial y firme, como máxima autoridad eclesiástica de la villa en que tiene lugar la ceremonia y toma del beneficio. Illescas y los procuradores de la iglesia de Belmonte van a ir siguiendo paso a paso el ritual acostumbrado en lo referente a las tomas de posesión de beneficios eclesiásticos, instándose finalmente a los clérigos y terceros de Alarcón a que acudieran con los frutos, rentas y obvenciones al cabildo de Belmonte ${ }^{49}$.

Entre tanto se ejecuta la incorporación, el provisor Spínola, se apresurará una vez más por su cuenta a apropiarse del mismo beneficio, tal y como ya había hecho con la prestamera de Monreal. Todos estos excesos dieron lugar a un prolongado pleito entre la iglesia de Belmonte y el provisor para esclarecer a quién correspondía disfrutar de las rentas eclesiásticas interceptadas por el clérigo italiano.

Ante las reclamaciones de Belmonte, la Santa Sede comisiona y designa como juez apostólico a fray Álvaro de Salas, prior del convento de San Agustín del Castillo de Garcimuñoz, para entender en el asunto de los anexos que habían sido arrebatados por Spínola. En junio de 1504, tras considerar el caso, exhortará a los dezmeros y demás implicados de Monreal y Alarcón a que entreguen a los de Belmonte los «diesmos de lana y ganado y queso y pan e vino y todas las otras cosas (...) non perjudicando los derechos que el dicho señor provisor tyene de los rediezmos de las dichas prestameras y benefiçio». De este modo pronuncia una sentencia salomónica en que intenta contentar a ambas partes, aunque el fallo distará mucho de ser definitivo, pues los problemas continúan entre la iglesia de Cuenca y la colegiata ${ }^{50}$.

En medio de este conflicto intervienen también los recaudadores puestos por Diego López Pacheco para tomar sus tercias, quienes intentan arrebatar las rentas eclesiásticas que Belmonte percibe en Alarcón. A los pocos meses los clérigos de San Bartolomé vuelven a quejarse de que los dezmeros de Alarcón ponen impedimentos para el traspaso en su favor de la renta del beneficio. Por consiguiente reclaman al marqués que interceda por ellos. Cuando don Diego se dirige a los responsables de Alarcón, éstos alegan que el alcaide de la villa, Diego del Castillo, retiene el montante del beneficio. Asimismo, uno de los arrendadores de las rentas aducirá que el provisor Spínola puso como tercero de la iglesia de Santiago al clérigo Lope de Villanueva, «e como cada yglesia tiene situados sus lugares para los cafyçes trahederos, que el dicho Lope de Villanueva, por virtud del dicho poder resçibio los cafyçes que le pertenesçieron en si como terçero, que pago al dicho provi-

${ }^{49}$ APB, Bulas, s.n (Alarcón, 1-junio-1504).

${ }^{50}$ APB, Bulas, s.n (Castillo de Garcimuñoz, 18-junio-1504).

Hispania Sacra, LX

121, enero-junio 2008, 95-130, ISSN: 0018-215-X 
sor». También dijo que el alcaide puso un candado en el edificio de la tercia para que él mismo pudiese hacerse con el pan del beneficio, y que cuando fueron a enviar desde la tercia el cereal correspondiente, comprobaron que estaba cerrada y que dentro no había ningún pan. Otro mayordomo afirmó que el alcaide tomó por la fuerza el cereal en nombre del colegio de Belmonte. Por tanto, hay mucha confusión en torno al beneficio, que denota cierta anarquía alrededor de la regulación del cobro de rentas eclesiásticas, y un evidente desamparo de los clérigos colegiales en relación con su percepción tributaria. Diríase que los oficiales del señor bloquean la tercia antes incluso de recibir instrucciones de éste, para evitar que los de Cuenca se lleven más de lo debido ${ }^{51}$.

En 1508 vuelven a surgir problemas en torno al cobro de las rentas. La epidemia de peste de 1507 , que afectó a todo el sureste peninsular, alcanza a Alarcón en abril de 1508, de tal manera que, como era común, los clérigos se ausentaron de la villa. Parece que Agustín de Spínola aprovechó esta situación de crisis para volver a la carga e insistir en su apropiación del beneficio de la iglesia de Santiago. La situación, pues, era tan delicada que los componentes de la colegiata de Belmonte, ante los continuos atropellos cometidos por el provisor genovés, mandarán en 1508 sacar sendos traslados de la bula de 1459, la consagración de 1460 y la posesión de 1504, dada la reanudación de las causas procesales. Al mismo tiempo, el bachiller Molina, tesorero del cabildo de Cuenca, pide (por indicación de Gómez Ballo, deán de la catedral) al clérigo puesto por él como dezmero, que desviase la renta del beneficio de Santiago hacia la mesa capitular catedralicia, violando con ello las bulas y cartas apostólicas, así como la sentencia de 1504. Los clérigos de Belmonte solicitaron al juez Salas que excomulgase por ello a Molina. Así pues, fray Álvaro tiene que tomar de nuevo cartas en el asunto, sin llegar a extremos como los que pedían los colegiales. Como el bachiller Molina había emitido carta de excomunión contra los dezmeros y carta citatoria contra los colegiales de Belmonte, el juez apostólico le exige que declare nulas estas letras, condicionándolo a la mencionada pena de excomunión.

No hay duda de que Spínola, aprovechó su posición de poder dentro de la curia romana para acabar consiguiendo el pleno control de las rentas en litigio. Sin sutilidad alguna, a principios de 1510 hizo excomulgar a los clérigos de la iglesia de San Bartolomé sólo por haberse querellado ellos contra su persona. En respuesta a la ofensiva, los clérigos colegiales solicitan a su compañero, Gregorio de Alarcón, que tramite en Roma la absolución, y también le encargan que intente solucionar los problemas de los beneficios de Spínola y Cardello y todo lo relacionado con la prestamera de Monreal.

\footnotetext{
${ }^{51} \mathrm{APB}$, Siglos XV-XVI, s.n ${ }^{\circ}$ (Escalona, 16-diciembre-1505; Alarcón 17-enero-1506).
} 
Ese mismo año Agustín de Spínola es nombrado obispo de Perugia. Este hecho pone de relevancia por una parte el ascendiente que disfruta en la corte pontificia, por otra la situación a la que ha llegado el tráfico de rentas beneficiales, que pasan a ser obtenidas por clérigos que viven en ciudades muy distantes del lugar de donde obtienen los beneficios, lo que redunda en el descuido del oficio y en que su relación con la iglesia parroquial se limite al simple cobro de la renta. Al año siguiente, Spínola consiguió ser designado arcediano de Alarcón, lo que le colocará en una situación óptima dentro de la diócesis para inducir a los clérigos locales a plegarse a sus caprichos. Así, ante la falta de concreción judicial, ese mismo año conseguirá que el cabildo de clérigos de Alarcón reconozca a Spínola sus derechos sobre el préstamo de Monreal y sobre el beneficio simple de Santiago, con los emolumentos propios de la mesa capitular de Belmonte. En total, las rentas ascendían a una cuantía de 32.000 maravedíes anuales «cum potestate et facultate transferendi et permutandi ${ }^{52}$. Así pues, a consecuencia de la airosa salida de Spínola en relación con los pleitos, pidió que se levantara a los de Belmonte la excomunión que había lanzado contra ellos ${ }^{53}$.

En suma, los abusos cometidos por Agustín de Spínola llevan a los clérigos del cabildo de Belmonte a elevar todo tipo de quejas tanto a las autoridades eclesiásticas como civiles, mientras «mícer Agustín» y su camarada Jacobo Cardello ganan unas ejecutorias que les ratifica en sus beneficios respectivos. Pero el frente contra los italianos ya se venía abriendo por otro flanco: los propios reyes tendrán que intervenir en amparo de la colegial, y así doña Juana expide una carta de revocación y paralización de dichas ejecutorias en razón de que los clérigos eran genoveses («pues seyendo estrangeros e no naturales de mis reynos no pueden thener los dichos benefiçios»). Sin embargo, estos enviarán a Diego de Cañete y a otros criados suyos a fijar las ejecutorias en la iglesia de Villaescusa, desatendiendo la carta de la reina. Ante la rebeldía y provocación, el 23 de marzo de 1510, el rey Fernando, en nombre de su hija, se dirige desde Madrid al gobernador del marquesado de Villena notificándole que los italianos deben remitir sus cartas de naturaleza -que los habilitan para tener los beneficios- al Consejo Real a fin de dilucidar la situación, y «que entre tanto se les secrestasen las rentas que tenian en estos mis regnos». Asimismo le piden que se coloque esa misma carta en las iglesias en las que dichos imputados tenían beneficios y que se comunique su contenido a los clérigos que ofician en su nombre ${ }^{54}$.

${ }^{52}$ APB, Siglos XV-XVI, s.n (Belmonte, 15-julio-1511); APB, Bulas, s.n (Cuenca, s.d., s.m., 1511). Spínola percibiría las rentas de Monreal y Alarcón en San Juan y Navidad.

${ }^{53}$ Sin embargo, hacia 1514 parece que Spínola haya renunciado a los beneficios usurpados, pues la colegiata arrienda el beneficio de Santo Domingo por 15.000 maravedíes; y todo los que tiene en Santiago (un beneficio, un préstamo y medio préstamo) más un préstamo en la Trinidad de Alarcón, conjuntamente por 27.510 maravedíes.

${ }^{54}$ APB, Bulas, s.nº (Madrid, 23-marzo-1510). El rey Fernando da al gobernador cincuenta días de plazo para cumplir los que le manda.

Hispania Sacra, LX

121, enero-junio 2008, 95-130, ISSN: 0018-215-X 
Asimismo, ya se ha indicado que hay otra forma de anexar beneficios, consistente en inducir a los componentes del cabildo local a que entreguen a la colegiata los beneficios que disfrutan en otras iglesias, un método alternativo de captación de rentas. Una muestra de este tipo de actuación la encontramos durante la década de los ochenta, en que Juan Díaz de Baños, uno de los canónigos de San Bartolomé, disfruta de medio préstamo en la iglesia parroquial de San Blas de Villarrobledo. Aprovechando la edad avanzada del clérigo, el colegio de Belmonte decidió incorporar a sus rentas las que percibía Díaz de Baños. De esta manera, en 1487 se tramitó una bula pontificia por la que el papa Inocencio VIII concedía la anexión de dicha media prestamera de Villarrobledo. Esta bula costó treinta mil maravedíes, lo que por otra parte indica que Roma aplicaba estos altos costes de gestión como método disuasorio para evitar un exceso de tráfico de beneficios ${ }^{55}$. Dos años más tarde Martín de Monreal, clérigo de Belmonte, hizo toma de posesión de la media prestamera. Algo parecido pudo pasar en 1510, cuando el cabildo de clérigos de Belmonte comisione al citado Gregorio de Alarcón para hacer diversos trámites en la Santa Sede, y también le encomienda la consecución de la bula pontificia de anexión de cierta media prestamera que disfrutaba su canónigo Juan Sánchez de la Cana. En la correspondencia mantenida entre la colegiata y su enviado, se le apremia a que agilice sus gestiones ante el temor de que fallezca el canónigo. Parece ser que la bula puede costar más de treinta ducados, lo que deja estupefactos a los colegiales que pensaban que no pasaría de ocho ${ }^{56}$.

Por último, la preponderancia que el cabildo de Belmonte ganó en la comarca, desatará los celos de otros grupos clericales. Así se detectan enfrentamientos con los frailes de San Francisco. Dado que los colegiales tenían la obligación de ir en procesión al convento mendicante a celebrar algunas misas de aniversario y los frailes no obtenían a cambio beneficio alguno, éstos acabaron impidiendo la celebración de las mencionadas ceremonias. La cuestión acabó siendo elevada en 1510 a instancias del administrador del obispado, Martín Cabeza de Vaca, obispo de Marruecos y visitador en el obispado de Cuenca, que resolvió de forma salomónica, pues exhortó a los de la colegiata a que realizaran sus celebraciones en otros cualesquier templos o ermitas de la villa, con lo que evitaba nuevos conflictos entre colectivos religiosos y dejaba a los frailes a salvo de intromisiones no deseadas ${ }^{57}$.

55 APB, Bulas, s.nº (Roma, 4-noviembre-1487; Belmonte, 15-junio-1510); Siglos XV-XVI (Villarrobledo, 6-agosto-1489). Cuando se produce la anexión de Villarrobledo, los clérigos del cabildo de la colegial se obligaron con Díaz de Baños en agradecimiento por su actitud, «a celebrar dos aniversarios (...): uno en el dia de San Miguel de septiembre por los señores marqueses y otro en Nuestra Señora de la Concepción, por los padres del canonigo» (APB, Censos, s.nº (s.1., s. f.)).

56 El ducado equivalía a 375 maravedíes, y a los de Belmonte les parece excesivo que la bula de anexión de media prestamera pueda superar los 11.375 maravedíes.

57 APB, Bulas, s.nº (Belmonte, 13-mayo-1510). 
Pero mientras el clero local atraviesa algún que otro contratiempo litigando en torno a la posesión de los beneficios incorporados, los vecinos lo premiarán con la cesión de multitud de censos y propiedades, a cambio por lo general de celebraciones pro anima. En este sentido entre 1487 y 1492 se registra una gran actividad de captación de rentas y tierras, recibidas en Belmonte y en las poblaciones próximas, siendo los propios capitulares destacados benefactores ${ }^{58}$.

\section{El testamento de Diego López Pacheco y la colegiata de San Bartolomé}

Prácticamente toda la vida política de Diego López Pacheco fue una continua e infructuosa lucha para recuperar en lo posible el pasado esplendor de su linaje, una vez que fue definitivamente derrotado por las tropas de los Reyes Católicos en 1480. «Fue el aristócrata rebelde más perjudicado por la guerra civil» ${ }^{59}$, aunque logró conservar un amplio patrimonio, lo que no le libró, bien es cierto, de apuros económicos. Una parte de sus considerables rentas la destinará a dotar de nuevo el gran proyecto eclesiástico de su familia en La Mancha, la colegial de Belmonte, en donde consolidó un núcleo de resistencia frente a las maniobras de los obispos y cabildo de Cuenca. Asimismo, ante el paroxismo a que llegan las tensiones entre Diego López Pacheco y la catedral, el marqués se ve empujado a emplear nuevas estrategias paralelas a fin de evitar la pérdida de poder sobre la iglesia de Belmonte. Así, uno de los manejos que acometió fue lograr en 1513 la primera tonsura para su hijo, el futuro marqués Diego Pacheco, a fin de que pudiera oficiar en la villa ${ }^{60}$.

Como hacen todos los nobles de la época Diego López Pacheco explicita a través de sus testamentos algunas de las líneas maestras de su política y propuestas religiosas. El 4 de abril de 1500, sintiéndose enfermo otorga una primera escritura testamentaria en la que están presentes algunas de las fundaciones del territorio que le queda de su otrora vasto señorío. De acuerdo con el documento, el marqués atenderá, al igual que sus antepasados, la fábrica del monasterio de San Agustín, en el Castillo de Garcimuñoz; y en su testamento final fechado el 6 de julio de 1528, concede 150.000 maravedíes para reparos y ornamentos del convento, al que por cierto, parecía haber olvidado en su anterior documento de últimas voluntades. Con igual cantidad obsequia al monasterio de Santa María de Gracia en la misma villa, y tampoco pasará por alto la do-

\footnotetext{
${ }^{58}$ Fernando Sánchez de Guadalajara dejará un censo de 450 maravedíes sobre sus casas junto al monasterio por un aniversario: APB, Censos, s.n ${ }^{\circ}$ (s.l., s.f.).

59 A. Franco Silva, Entre la derrota y la esperanza. Don Diego López Pacheco, marqués de Villena, Cádiz 2005, p. 163,

${ }^{60}$ AHN Nobleza, Frías, leg. 677, nº 1.

Hispania Sacra, LX

121, enero-junio 2008, 95-130, ISSN: 0018-215-X
} 
tación del hospital de San Andrés de Belmonte al que destina cincuenta mil maravedíes.

Según este segundo testamento, los clérigos colegiales de San Bartolomé tendrían que oficiar cuatro capellanías, las cuales ya se contemplaban en la escritura de 1500. Una capellanía se debería celebrar en memoria de su hijo, el conde Juan Pacheco de Luna. Pretende que los capellanes -que serán designados por sus sucesores en el título de marqués- digan una misa diaria por el fallecido conde. Las otras tres capellanías se crean para oficiar otras tantas misas diarias por sus familiares y también por aquellos acreedores cuya deuda él hubiera olvidado abonar. Las cuatro fundaciones recibirían veinte mil maravedíes de un juro de heredad tomado de las rentas que el marqués percibe en Cuenca, y viene a modificar una dotación algo más generosa que se contemplaba en el testamento de $1500^{61}$. Los maravedíes de las capellanías, en tanto se tomaban del juro, se sacarían de la alcabala de los atajos, que los oficiales de Belmonte deberían abonar por tercios hasta el reemplazo del juro.

Concluía así todo el proceso de transferencia de bienes materiales y de asegurar el funcionamiento de la iglesia de Belmonte. Al marqués sólo le quedaba garantizar el respaldo de la casa de Pacheco a la institución, por lo que cedió su derecho de presentación de los clérigos prebendados de la colegiata a su hijo el marqués de Moya, como heredero del mayorazgo de Villena. De este modo la familia del fundador y la fundación quedaban unidas a perpetuidad... hasta que la implantación del Estado liberal desmantelara el sistema de patronazgos y derechos de presentación sobre las entidades eclesiásticas.

\section{CONCLUSIONES}

Como balance de todo lo expuesto, en primer lugar comprobamos cómo la familia Pacheco consigue consolidar a la villa de Belmonte como sede principal de su extenso señorío de Villena. Para ello contará con la promoción de importantes iniciativas eclesiásticas en dicha población, si bien su proyecto más importante se va a ver materializado bajo la gestión personal de Juan Pacheco con la transformación de la iglesia parroquial de San Bartolomé en templo colegial, el único existente en todo el cuadrante sureste de Castilla. Con los estatutos, dotación, establecimiento de memorias fúnebres y demás disposiciones, los Pacheco harán de este templo una especie de catedral particular.

${ }^{61}$ En el testamento de 1528, don Diego olvida a los que murieron a sus órdenes en los cercos de Madrid y Trujillo y en otras fortalezas que mantuvo cercadas con sus tropas en la guerra castellana. Para estos tenía reservados los correspondientes sufragios en las capellanías de Belmonte, lo que demuestra por su parte cierta dignidad personal, que a la postre se desvanece (A. FRANCO SiLVA, Entre la derrota y la esperanza, p. 104). 
Juan Pacheco pretenderá reformar un templo mediante el cual poder controlar la vida religiosa de la comarca, ejercer influencia sobre los clérigos que ofician en su señorío y sobre todo poder establecer un contrapoder con respecto al obispado de Cuenca. La presencia de Lope de Barrientos al frente de la diócesis será un factor fundamental para que el marqués de Villena forje todo su entramado eclesiástico en Belmonte. En consecuencia, solicitará en todo momento al pontífice de turno que exija a la iglesia conquense que no se inmiscuya en sus planes eclesiales. Con ello dará culminación no sólo a un proceso de fortalecimiento de la parroquia de su villa natal, sino también a un proyecto de promoción personal, que acarreaba la consolidación de sus propias clientelas, así como un abierto desafío al sector de la iglesia conquense alineado en su contra. Por esta razón, aun después de legar a su hijo Diego la titularidad del marquesado (1467), Pacheco continuará proporcionando su apoyo al templo.

Los derechos adquiridos por los marqueses de Villena en la iglesia de San Bartolomé serán continuamente vigilados y hasta combatidos por canónigos y dignidades de la catedral de Cuenca, y tanto uno como otro marqués harán frente común con la clerecía de Belmonte en la defensa de sus intereses, pero en este sentido don Diego va a ir mucho más lejos que su padre, sobre todo ante las enormes trabas y usurpaciones de rentas que oponen algunos clérigos del cabildo catedralicio (los genoveses Spínola y Cardello) durante la etapa del obispo Rafael Riario. Coincidiendo con la ofensiva emprendida por el provisor Spínola a fin de controlar los medios de sustentación de la colegial, Diego López Pacheco obtendrá - no sin grandes esfuerzos administrativos y económicos- los derechos de patronato y de presentación de clérigos de la colegiata. Asimismo su coincidencia cronológica con Diego de Iniesta al frente del cabildo de Belmonte le garantizará la plena cohesión con los clérigos, quienes emprenden todo tipo de maniobras en coalición con el marqués. Estos ardides pasan por la elevación de denuncias, las súplicas a diversas instancias superiores, la consecución de privilegios, la fundación y ratificación de los citados derechos de patronato y presentación por parte del marqués, la marcha a Talavera a compilar documentación que respalde sus privilegios... Pero en realidad podemos afirmar que la consecución de prerrogativas por parte del marqués no viene sino a enmascarar el declive y la pérdida de poder real que su linaje sufre dentro del nuevo Estado autoritario tras su derrota en la guerra civil.

Así pues, la evolución de la iglesia colegial en sus primeros años -desde los avatares de su erección a mediados del siglo hasta los incesantes pleitos entablados entre los capitulares de Cuenca y los clérigos colegiados- viene en cierto modo a reproducir los conflictos civiles que tanto Juan como Diego López Pacheco protagonizarán a lo largo de sus vidas. Y a la postre será el reflejo del declive de su linaje.

Hispania Sacra, LX

121, enero-junio 2008, 95-130, ISSN: 0018-215-X 
Pero no menos importante es el método de financiación de la iglesia colegial, basado en la anexión de beneficios, es decir en la captación de rentas procedentes de otras iglesias (así como de la extinta parroquia de Belmonte). La incorporación de beneficios a la mesa capitular de Belmonte se hizo de manera extremadamente lenta, tanto por la tardanza en quedar disponibles, como por las trabas que interpusieron Spínola y otros clérigos de la catedral. Ante tanta inseguridad, todavía en 1501 la colegiata sigue exhibiendo y ejerciendo su derecho de anexar beneficios vacantes dentro de la jurisdicción del marquesado. En esta ocasión esta potestad ya sólo es aplicable en aquella parte del señorío de Villena que ha quedado en poder de Diego López Pacheco después de las pérdidas territoriales recibidas con ocasión de su derrota en la contienda castellana. Este proceso de traspaso de riqueza que circula de aquellas parroquias de donde se extraen las rentas hacia la colegiata es un fenómeno común a todas las iglesias colegiales, que viene a manifestar el sistema parasitario de transferencia del capital de unas poblaciones a otras a través de las instituciones eclesiásticas.

Asimismo, en virtud del traspaso del beneficio de las parroquias a terceros, los oficios asociados a dicha renta pasan a ser ocupados por clérigos asalariados por la colegiata, lo que lleva a una proletarización de estos componentes del bajo clero secular, y que a su vez podría redundar en ellos en una falta de incentivo para cumplir rectamente con su oficio.

Por último hemos de volver sobre la presencia de los clérigos especuladores genoveses en la catedral de Cuenca y su repercusión en la colegial de San Bartolomé. La aparición en Cuenca de Agustín de Spínola, mano derecha del obispo italiano Rafael Riario, y de su compañero Jacobo Cardello significa no sólo la aceptación del desvergonzado absentismo del cardenal de San Jorge, sino sobre todo de la rapiña de sus protegidos. La actuación de Spínola y Cardello en la colegiata de San Bartolomé de Belmonte con el beneplácito del cardenal Riario y del provisor Pedro de Costa sirve de paradigma del comportamiento de la facción de los genoveses durante su estancia en el cabildo y en la ciudad de Cuenca. Los italianos se convierten en un pequeño clan caracterizado por la avidez de rentas y la impunidad que el amparo de Riario les otorga. Aprovechando su situación de poder, disponen a su antojo de las rentas y cargos eclesiásticos, violando a veces las propias disposiciones pontificias. En concreto, Agustín de Spinola junto al deán Francisco Hurtado de Mendoza intentarán oponer todos los obstáculos posibles al patronazgo de Diego López Pacheco en el templo manchego, pese a que el propio pontífice Alejandro VI ratificará tal derecho al noble. Pero esta potestad no sería extensible a los beneficios servideros y al préstamo que había en la iglesia antes de transformarse en colegiata, por lo que Jacobo Cardello se hace adjudicar un beneficio simple vacante. Así, con Riario en el obispado, Spínola en el gobierno de la diócesis y Cardello con un beneficio en la iglesia de San Bartolomé, los componentes de ésta verán pe- 
ligrar su autonomía y no descansarán hasta que los italianos desaparezcan de Cuenca.

\section{APÉNDICE DOCUMENTAL}

\section{9, diciembre 1. Mantua.}

Bula de Pío II por la que erige la colegiata de San Bartolomé de Belmonte, con sus dignidades, canónigos, racioneros y capellanes, y se establece el derecho de anexar los beneficios que quedaren vacantes en las poblaciones pertenecientes al marqués de Villena en los obispados de Cuenca y Cartagena (traslado de 1486).

APB: Bulario, $\mathrm{n}^{\circ} 6$.

Pius, episcopus, seruus seruorum Dei, venerabilibus fratris episcopus Burgensis, salutem et apostolicam benedictionem.

Ex superue prouidentia majestatis in apostolice dignitate specula constitutis circa vniuersarum quarum nobis de super comissa cura est ecclesiarum profectus et quomoda sicuti ex debito nobis pastoralis incumbit officii studiis intendamus assiduis et ipsarum starum pro ut verum pensatis circunstantiis congruere terminus in melius dirigere ac uberioris eas honoris titulis attollere studemus votis illis graciosum conferentes anditum per que frequentioris deuotionis ardore portionibusque laudum preconis venerari complectitur altissimis et pro animarum propagatione salutis ubilibet continuum diuinorum cultus suscipiat incrementum sane pro parte dilecti filii nobilis viri Johannis Pacheco, marchionis de Villena, nobis super exhibita petitio continebat, quod in diocesis Conchensis nulla collegiata ecclesia fore dignosciur instituta. Et si parrochialis ecclesia Sancti Bartholomei, oppidi de Belmonte, eiusdem diocesis temporali dominio dicti marchionis subiecti in loco in signi populoso et eminenti constituta in qua no nulla beneficia ecclesiastica seruitoria ac prestimonia fore noscuntur instituta et in suiis facultatibus conpetenter habundans in secularem collegiatam ecclesiam exigeretur nec non vnus prioratus secularis, vna cantoria, vna thesauraria ac sex canonicatus et prebende qui quid prioratus electimus et principalis ac cantoria que secunda ac thesauraria que tercia non tamen principales neque curate et electiue dignitates censeantur quatuor vero portiones et quatuor capellanie perpetue sine cura totidem personis ydoneis de quarum numero modernus ipsius ecclesie rector inibi prior tamquam caput eficeretur asignandi et qui prior prioratum ac sex canonici canonicatus et prebendas huiusmodi pro tempore obtinentes capitulum in simul facerent ipseque prior curam animarum parrochianorum eiusdem ecclesie haberet et illam exercere deberet de nouo crearentut et instituerentur nec non ipsi prioratus, cantoria, thesauraria, canonicatus et pre- 
bende ac portiones et capellanie tam super dicte ecclesie et in illa institutorum beneficiorum que prestimonialium portionum et simplicium beneficiorum de quibus infra dicetur fructibus, redditibus et prouentibus dotarentur et fundarentur per hoc diuinis cultus in ipsa ecclesia que plurimum susciperet incrementum id que cederet ad decorem et venustatem ecclesie et oppidi predictorum. Quare pro parte dicti marchionis aserentis se ad dictam ecclesiam singularem deuotionem gerere nobis fuit humiliter supplicatum ut dictam parrochialem in secularem collegiatam ecclesiam erigere et in eam prioratum, cantoria et tesauraria canonicatus et prebendas portiones et capellanias predictos creare et instituere nec non ipsi ecclesie exigende et illius mese capitulari cuius omnium prestimoniorum prestimonialiem portionum seu simplicium ac seruitiorum in illa instituorum quorum fructum redditum et prouentum veros annos valores presentibus pro expressis habentes omnia et singula alia prestimonia, prestimoniales portiones et simplicia beneficia tam in prefato oppido quam in aliis terris et dominiis dicte marchionis in Conchensis et Carthaginensis diocesis consistentia quorum trecentarum quinquaginta librarum Turonensis paruorum, fructus redditus et prouentibus secundum comunem extimationem valorem anuum non excedant perpetuo vnire, anectere et incorporare ac alias super hiis opportune prouidere de benignitate apostolica dignaremur. Nos igitur qui cultum eundem uigere et ad augeri intensis desideriis affectamus huiusmodi supplicationibus inclinati fraternitati tue per apostolica scripta comictimus et mandamus quatenus si est ita parrochialem ecclesiam predictam in secullarem et collegiatam ecclesiam cum omnibus et singulis honoribus, prerogatiuis, preeminentiis, indultis, priuillegiis, gratiis, exentionibus et insignis collegialis ad instar aliarum collegiatarum ecclesiarum partium circum uicinarum auctoritate nostra erigas ac in eam vnum prioratum secularem, vnam cantoriam et unam thesaurariam nec non sex canonicatus et prebendas quatuor portiones et quatuor capellanias perpetuas cum modis et conditionibus predictis eadem auctoritate exeens et instituas ac etiam seruitoria en dicta ecclesia instituta nec non prestimonia prestimoniales portiones et simplicia beneficia eiusdem et aliorum ecclesiam locorum dicti marchionis ut prefertur quorum nomina conomina loca et designationis presentibus haberi volumus pro expressis cum per cessum vel decessum seu quauis aliam dimisionem quorumcumque illa obtinentium vacare contigerit cum omnibus juribus et pertinentiis suis dicte erigende ecclesie ac illus mense capitulari in perpetuum vnias, anectes et incorpores ita quidem ex tunc cum vacauerint et perfertur liceat eisdem priori et capitulo per se uel alium seu alios corporalem prestimoniorum prestimonialium portionem et beneficiorum simplicium seruitoriorum juriumque et pertinentiarum predictorum possessionem auctorita propria aprehendere ac illorum fructus in suos et dicte erigende ecclesie usus et vtilitatem conuertere et perpetuo retinere diocesani loci et cuiuscumque alterius licentia super hoc minime requisita; et in super si et postquam erectionem, creationem, institutionem, vnionem, anexionem et incorpo- 
rationem predictas per te vigore presentium fieri contigerit ut prefertur de et super omnibus et singulis fructibus, redditibus et prouentibus tam ecclesie erigende et beneficiorum in illa institutorum quam prestimoniorum prestimonialium portionum et simplicium etiam seruitoriorum beneficiorum huiusmodi prioratum, cantoriam, thesaurariam, canonicatus et prebendas, portiones et capellanias predictas pro ut tibi expedire videbitur dotes, fundes et dotem ipsam illa asignes nec non prioratum moderno rectori dicte ecclesie si ydoneus existat alio quim alteri idonee persone de quatibi videbitur ac cantoriam, thesauraria, canonicatus et prebendas, portiones et capellanias predictas pro hac prima vice vacantes singulis aliis personis idoneis perte ad hoc eligendis cum omnibus juribus et pertinentiis suis conferas et prouideas etiamde eisdem omnesque fructus redditus et prouentus huiusmodi eisdem tam pro prebendis grossis quam pro distributionibus cotidianiis et aniuersariis ac aliis diuinis officiis diuidas atque distribuas pro ut tibi expedire etiam vissum fuerit ac alia facias statuas, ordines, decernas et exequaris que cura premissa nescesaria fuerint et opportuna auctoritate nostra supradicta contradictiones per censuram ecclesiasticam appelationes postposita compescendo non obstantibus costitutionibus et ordinationibus apostolicis ceterisque contrariis quibuscumque ante si aliqui super prouissionibus sibi faciendis de prestimoniis prestimonialibus portionibus et huiusmodi vel aliis beneficiis ecclesiasticis in illis partibus speciales vel generales Apostolice Sedis vel legatorum eius literas impetrarint etiam si per eas ad inhibitionem reseruationem et decretum vel alias quomodolibet sit processum quas quidem literas et processus habitos per easdem et quecumque inde secuta quo ad prestimonia prestimoniales portiones et simplicia etiam seruitoria beneficia huiusmodi vnienda volumus non extendi sed nullum per hoc eis quo ad executionem prestimoniorum prestimonialium portionem vel beneficiorum aliorum pre judicum grauari et quibus libet aliis priuillegiis, indulgentiis et literis apostolicis generalibus vel specialibus quorumcumque tenorem existant per que presentibus non expressa vel totaliter non inserta effectus earum impediri valeat quomodolibet vel defferri et de quibus quorumque totis tenoribus de verbo ad verbum habenda sit in nostris litteris mentio specialis. Nos enim ex nunc irritum decernimus et inane si secus super hiis a quoquam quauis auctoritate scienter uel ignoranter contingerit attemptari.

Datum Mantue, anno incarnationis Dominicae millessimo quadragentessimo nono, kalendas decembris, pontificatus nostri anno secundo. 